\title{
Biorefinery Gets Hot: Thermophilic Enzymes and Microorganisms for Second-Generation Bioethanol Production
}

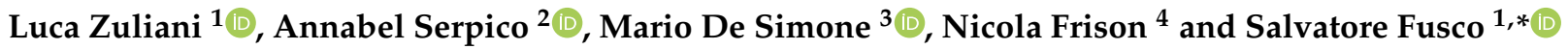 \\ 1 Biochemistry and Industrial Biotechnology Laboratory, Department of Biotechnology, University of Verona, \\ 37134 Verona, Italy; luca.zuliani@univr.it \\ 2 Applied Microbiology \& Biotechnologies, Circular Economy Business Unit, Leitat Technological Center, \\ 08225 Terrassa, Barcelona, Spain; aserpico@leitat.org \\ 3 Instituto de Tecnologia Química e Biológica António Xavier, Universidade NOVA de Lisboa, \\ 2780-157 Lisbon, Portugal; msimone@itqb.unl.pt \\ 4 Chemical, Environment and Bioprocesses Engineering Laboratory, Department of Biotechnology, \\ University of Verona, 37134 Verona, Italy; nicola.frison@univr.it \\ * Correspondence: salvatore.fusco@univr.it
}

Citation: Zuliani, L.; Serpico, A.; De Simone, M.; Frison, N.; Fusco, S. Biorefinery Gets Hot: Thermophilic Enzymes and Microorganisms for Second-Generation Bioethanol Production. Processes 2021, 9, 1583. https://doi.org/10.3390/pr9091583

Academic Editors: Antonio D. Moreno and Paloma Manzanares

Received: 30 July 2021

Accepted: 1 September 2021

Published: 3 September 2021

Publisher's Note: MDPI stays neutral with regard to jurisdictional claims in published maps and institutional affiliations.

Copyright: () 2021 by the authors. Licensee MDPI, Basel, Switzerland. This article is an open access article distributed under the terms and conditions of the Creative Commons Attribution (CC BY) license (https:// creativecommons.org/licenses/by/ $4.0 /)$.

\begin{abstract}
To mitigate the current global energy and the environmental crisis, biofuels such as bioethanol have progressively gained attention from both scientific and industrial perspectives. However, at present, commercialized bioethanol is mainly derived from edible crops, thus raising serious concerns given its competition with feed production. For this reason, lignocellulosic biomasses (LCBs) have been recognized as important alternatives for bioethanol production. Because LCBs supply is sustainable, abundant, widespread, and cheap, LCBs-derived bioethanol currently represents one of the most viable solutions to meet the global demand for liquid fuel. However, the cost-effective conversion of LCBs into ethanol remains a challenge and its implementation has been hampered by several bottlenecks that must still be tackled. Among other factors related to the challenging and variable nature of LCBs, we highlight: (i) energy-demanding pretreatments, (ii) expensive hydrolytic enzyme blends, and (iii) the need for microorganisms that can ferment mixed sugars. In this regard, thermophiles represent valuable tools to overcome some of these limitations. Thus, the aim of this review is to provide an overview of the state-of-the-art technologies involved, such as the use of thermophilic enzymes and microorganisms in industrial-relevant conditions, and to propose possible means to implement thermophiles into second-generation ethanol biorefineries that are already in operation.
\end{abstract}

Keywords: bioethanol; thermophiles; lignocellulose; second-generation biorefinery; biotechnology

\section{Introduction}

\subsection{Need for Alternative Fuels}

Carbon dioxide is one of the major greenhouse gases (GHGs) responsible for global warming; indeed, its atmospheric levels have significantly and uncontrollably increased since the Industrial Revolution to roughly 420 ppm, as of May 2021 [1]. If no countermeasures are put into place, its atmospheric concentration is projected to exceed $900 \mathrm{ppm}$ by the end of the century [2]. Among other reasons, the use of fossil fuels is one of the main causes of $\mathrm{CO}_{2}$ emission, accounting for $78 \%$ of total GHGs emissions [3]. Considering that the global population is expected to grow to around 9.7 billion by 2050, a dramatic rise in fossil fuel demand is expected in the near future, exacerbated by a shift toward higher living standards in developing countries. As a consequence, the bioethanol sector is expected to grow noticeably, with global sales forecast to be about 140 billion liters in 2022 [4,5]. In addition to its environmental advantage, bioethanol shows some other key benefits that make it an ideal alternative to fossil counterparts. First, it is compatible with current gasoline engines because it can be employed as a blend with petrol (i.e., 5 or 10\%) 
or at a higher percentage (up to 85\%) when used in flex-fuel vehicles. Furthermore, its high oxygen content (i.e., 35\%) and octane number result in cleaner combustion with minimal particulate, hydrocarbon, and nitrogen oxide emissions compared to fossil-based fuels [6].

Today, most of the currently commercialized bioethanol is crop derived [6] and mainly produced from starchy and/or oleaginous crops, known as first-generation (1G) bioethanol (Figure 1). However, its use poses serious concern in relation to the food vs. fuel debate $[7,8]$. Indeed, the price of food commodities can be influenced by the consumption of the same crops for biofuel production [9]. For this reason, the prospect of utilizing non-food feedstocks to produce so-called second-generation (2G) bioethanol is of significant interest (Figure 1). An augmented demand for alternative and sustainable biofuels is driving the need for biorefineries capable of utilizing renewable and environmentally friendly feedstocks. In this regard, lignocellulosic biomasses (LCBs) are the most abundant and relatively cheap type of biomass available, thus representing a desirable feedstock for $2 \mathrm{G}$ bioethanol production. To date, LCBs-derived bioethanol represents one of the most marketable solutions to meet the global demand for liquid fuel, while mitigating the atmospheric pollution caused by $\mathrm{CO}_{2}$ emissions [10]. Processes described in the literature show the use of a plethora of LCBs to produce bioethanol, including sugarcane bagasse, wheat straw, switchgrass, corn stover, fruit and vegetable peels, and paper waste. Nonetheless, in 2016 less than $1 \%$ of the globally produced bioethanol derived from non-food feedstocks [6]. The main drawbacks to the global adoption of $2 \mathrm{G}$ bioethanol are primarily related to (i) the logistics of procurement of the raw material [11], (ii) the large capital costs involved, and (iii) the high technological risks [12]. Indeed, unlike 1G biomasses, LCBs are not directly accessible as a carbon and energy source by most microorganisms; therefore, they need to be subjected to a series of transformations (size reduction, pretreatment, and enzymatic hydrolysis) to extract fermentable sugars that can be fermented to ethanol (see below).

\section{Feedstocks Pros Cons}

\begin{tabular}{|c|c|c|c|}
\hline $\begin{array}{c}1^{\text {st }} \text { Generation } \\
\qquad A\end{array}$ & $\begin{array}{l}\text { Edible biomasses: } \\
\text { - Corn } \\
\text { - Sugar cane } \\
\text { - Sugar beet } \\
\text { - Wheat }\end{array}$ & $\begin{array}{l}\text { - Up to } 60 \% \text { reduction of GHG } \\
\text { emission compared to fossil } \\
\text { fuels } \\
\text { - Easy hydrolyzable biomasses }\end{array}$ & $\begin{array}{l}\text { - Intensive use of arable lands } \\
\text { - Competition with food and } \\
\text { feed production }\end{array}$ \\
\hline $2^{\text {nd }}$ Generation & $\begin{array}{l}\text { Non-edible biomasses: } \\
\text { - Wood - Paper waste } \\
\text { - Straw } \quad \text { - Fruit and } \\
\text { - Grass } \quad \text { vegetable peels } \\
\text { - Waste }\end{array}$ & $\begin{array}{l}\text { - High availability } \\
\text { - Widespread } \\
\text { - Cheap }\end{array}$ & $\begin{array}{l}\text { - } \text { Recalcitrant to hydrolysis } \\
\text { - Biomass logistic of } \\
\text { procurement } \\
\text { - Formation of microbial } \\
\text { inhibitors during pre- } \\
\text { treatment }\end{array}$ \\
\hline $\begin{array}{c}3^{\text {rd }} \text { Generation } \\
.55\end{array}$ & $\begin{array}{l}\text { Algal biomass } \\
\text { - Microalgae } \\
\text { - Macroalgae } \\
\text { - Cyanobacteria }\end{array}$ & $\begin{array}{l}\text { - High photosynthetic } \\
\text { efficiency } \\
\text { - } \quad \text { No competition for arable } \\
\text { land and drinkable water } \\
\text { - } \quad \text { Cultivation coupled to } \\
\text { wastewater treatment }\end{array}$ & $\begin{array}{l}\text { - Higher greenhouse gas } \\
\text { emission than } 2 \mathrm{G} \\
\text { - } \quad \text { Large-scale feasibility }\end{array}$ \\
\hline $4^{\text {th }}$ Generation & $\begin{array}{l}\text { Genetically modified } \\
\text { microorganism } \\
\text { - Microalgae } \\
\text { - Cyanobacteria } \\
\text { - Yeast }\end{array}$ & $\begin{array}{l}\text { - Improved photosynthetic } \\
\text { efficiency and biomass } \\
\text { accumulation }\end{array}$ & - Early stage of development \\
\hline
\end{tabular}

Figure 1. The four bioethanol generations. 
Lignocellulose is the major output of photosynthesis, as the main structural component of all plants. It is a complex matrix of carbohydrate-based (cellulose and hemicellulose) and phenolic-based (lignin) biopolymers. Cellulose, the most abundant organic compound on Earth, is the major constituent of plants' cell wall, contributing an average of 35 to $50 \%$ to plant dry biomass $[13,14]$. It is a linear homopolymer of glucose linked via $\beta-1,4$-glycosidic bonds, in which the repeating unit is cellobiose. Supramolecular analysis of cellulose reveals that adjacent cellulose chains can interact with each other via hydrogen bonds, leading to the formation of microfibrils that, in turn, can associate with macrofibrils and finally form cellulose fibers. Tightly packed and interconnected cellulose fibers constitute the crystalline regions of cellulose, whereas less organized sections are known as amorphous regions (Figure 2) [15]. Hemicellulose(s), the second most abundant components of LCBs (20 to $35 \%$ of dry biomass weight), are a family of branched and heterogeneous polymers, with a chemical composition that varies among different plant tissues and species. It consists of C5 sugars (i.e., xylose and arabinose) and/or C6 sugars (i.e., glucose, mannose, and galactose). For instance, whereas softwoods predominantly contain mannose, hardwoods and agricultural residues are generally characterized by the presence of xylose $[5,16]$. One of the main roles of hemicellulose(s) is to interconnect and wrap together the cellulose fibers. Lignin is a nonlinear polymer, composed of randomly linked aromatic moieties, including coniferyl, sinapyl, and p-coumaryl alcohol. Lignin is linked both to hemicellulose and cellulose and acts as a barrier, preventing the penetration of chemicals and enzymes, thus conferring to lignocellulose its structural strength and recalcitrancy [17].

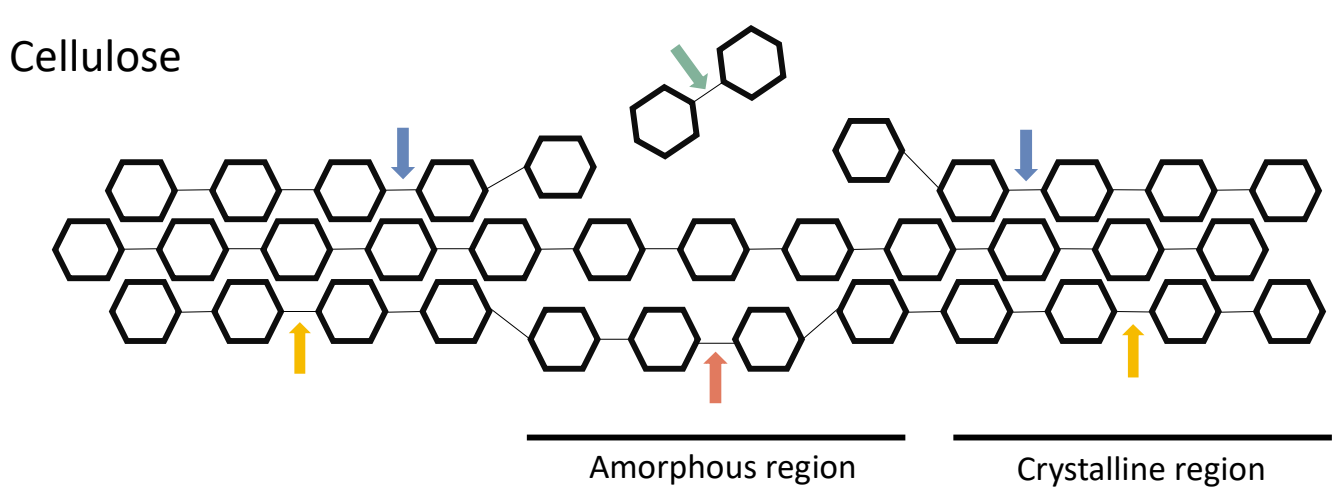

Hemicellulose

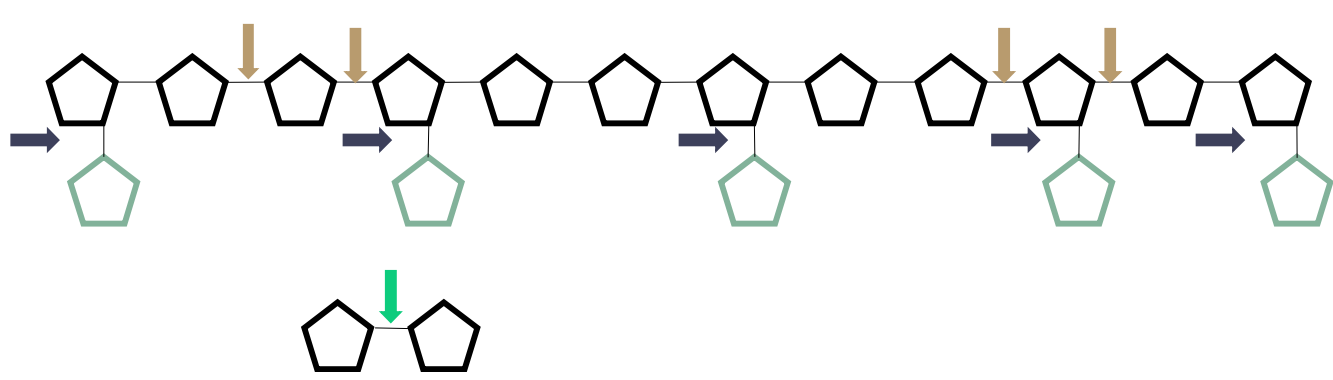

Exoglucanse

Endoglucanase

$\beta$-glucosidase LPMOS

$\square$ Cellobiose

$\square$ Glucose

$\beta$-D-xylosidase

Endo-1,4 $\beta$-xylanase

$\rightarrow \beta$-D-xylosidase

$\triangle$ Xylose

L-arabinose

Figure 2. Schematic view of cellulose and hemicellulose hydrolysis.

Depolymerization of lignocellulose is a complex process that requires the concerted action of many microbial enzymes. Cellulose chains are first degraded by the combined action of two classes of cellulases: endoglucases and exoglucanases (also known as cellobiohydrolases) [18]. Endoglucanases act randomly, cleaving internal glycosidic bonds and releasing oligosaccharides of different lengths, whereas cellobiohydrolases act on cellulose ends, releasing cellobiose [19]. The process is completed by $\beta$-glucosidases, which further hydrolyze cellobiose units to glucose (Figure 2). Unlike cellulose, the hydrolysis of the hemicellulose component requires several different enzymes, due to its high heterogeneity [20]. Because xylan is, on average, the most abundant component of hemicellulose (over 
$70 \%$ of its structure), xylanases are the most used hemicellulases for industrial applications, because they can hydrolyze the $\beta-1,4$ bond and produce oligomers, which can then be further hydrolyzed into xylose by $\beta$-xylosidase [5]. To fully degrade hemicellulose, additional enzymes, such as $\beta$-mannanases, arabinofuranosidases, or $\alpha$-L-arabinases, are required depending on the hemicellulose composition, which can be mannan- or arabinofuranosylbased [21]. The current production of bioethanol from renewable feedstock has been hampered by economic barriers, primarily linked to the challenging nature of the LCBs [22]. Chemical, physical, biological, and combined pretreatments of LCBs are necessary to separate their components and make them more accessible for the following enzymatic hydrolysis (see below).

Although the focus of this review is on $2 \mathrm{G}$ bioethanol production because it is the technology that is (after 1G bioethanol) closest to a marketable solution, the other two generations are briefly described for completeness. The third generation of biofuels (3G) involves the utilization of microalgae, macroalgae, and cyanobacteria biomasses (Figure 1). Microalgal cultivation, unlike that of $1 \mathrm{G}$ and $2 \mathrm{G}$ feedstocks, can take place on non-arable lands, thus completely avoiding space competition with food and feed production [23]. The costeffectiveness of $3 \mathrm{G}$ biofuel is increased by coupling microalgae cultivation with wastewater remediation [24], taking advantage of the ability of microalgae to uptake inorganic nitrogen and phosphorous [25-27]. However, at the current developmental stage, algal biofuel is not a feasible option, because the biomass yield does not meet industrial requirements for profitability [28,29], particularly taking into consideration the elevated energetic input required by algal cultivation, harvesting, and processing [30-32]. By comparison, the fourth generation of biofuels $(4 \mathrm{G})$ involves the application of genetic engineering of microalgae, yeasts, fungi, and cyanobacteria to improve the overall biomass yield and reduce the carbon footprint of the conversion process [33] (Figure 1). Fourth generation development is still at an early stage, and the environmental concerns raised about the use of genetically modified organisms pose some limitations to its broad adoption [34,35]. Although further research is needed to improve the yields of all biofuel generations, considering the advantages and disadvantages of each generation, the most likely future of biofuel production may consist of the integration of some or all four generations [33].

\subsection{Bioethanol Biorefinery: State of the Art and Challenges}

Bioethanol production from lignocellulosic feedstocks can be separated into four main phases: (i) pretreatment, (ii) hydrolysis (saccharification), (iii) fermentation, and (iv) product recovery. The pretreatment phase improves lignocellulose digestibility by subjecting the biomass to a range of physical, chemical, physico-chemical, and biological treatments, or combinations thereof. This step is needed to make the LCBs more accessible to the hydrolytic enzymes used during saccharification. Different pretreatment strategies are extensively reviewed in [36,37] and summarized in Figure 3. Regardless of the chosen pretreatment, LCBs need first to be physically reduced in size to increase the effectiveness of the subsequent processes. Moreover, it is important to note that pretreatment strategies vary in the function of the biomass origin and composition [38]. Steam explosion is one of the most common and effective pretreatment options, because it makes use of high temperatures (160 to $260^{\circ} \mathrm{C}$ ) and a sudden decompression to efficiently disrupt lignocellulose fibers [39]. It can be easily combined with the use of dilute alkali or acid solutions [40]. The current challenge in the pretreatment phase is the development of a versatile technology effective on a variety of substrates while using milder conditions, thus diminishing its environmental and economic impact. Pretreatment can be followed by a detoxification phase, which aims to remove inhibiting and toxic compounds (i.e., furans, phenolics, and weak acids) formed during the previous stage [41,42], making use of the different approaches reviewed in [43]. Finally, the pretreated LCB is subjected to a conditioning step to adjust the $\mathrm{pH}$, temperature, and solids content of the bioreactor vessel [44]. Then, the pretreated and detoxified biomass is converted into fermentable sugars by the activity of a moderate thermophilic enzyme blend (e.g., Cellic CTec2 or 
more advanced enzyme products). The technical and economic feasibility of the entire bioethanol production process is dependent on the successful conversion of the LCB into fermentable sugars. Therefore, in addition to the selection of an appropriate enzymatic mixture, parameters such as enzyme and solid loadings, shaking rate, use of additives, and hydrolysis time, play a fundamental role [36]. Sugar fermentation is generally realized through a batch setup in a stirred tank reactor, and performed by robust industrial strains able to produce and withstand high ethanol titers, such as Saccharomyces cerevisiae.

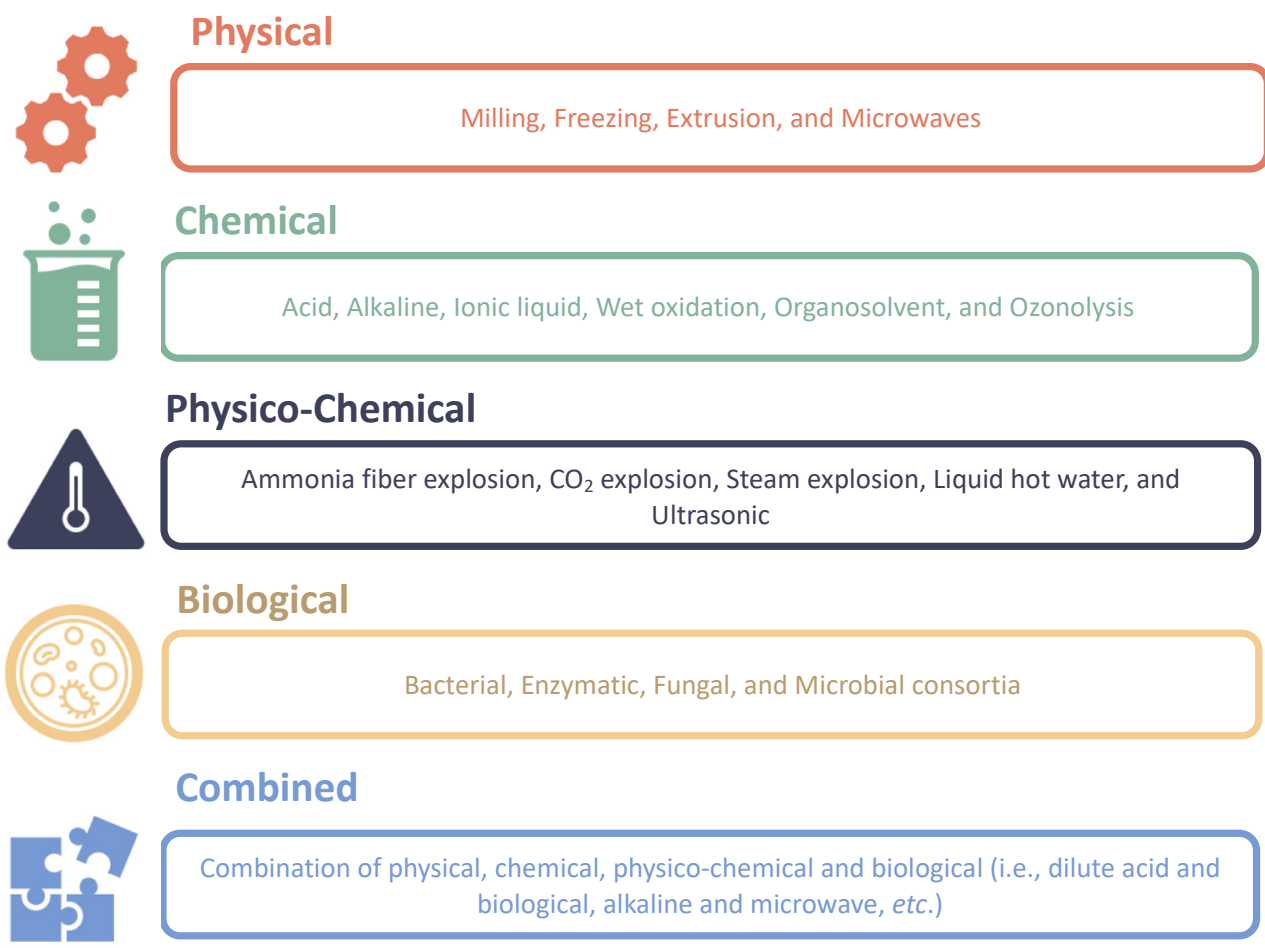

Figure 3. Types and examples of pre-treatment methods.

The separate hydrolysis and fermentation (SHF) process (Figure 4) is the classic method to produce bioethanol from LCBs, in which saccharification (hydrolysis) of the biomass is carried out in a different bioreactor (at $45-55{ }^{\circ} \mathrm{C}$ ) than that used for its fermentation to ethanol (at $30-37^{\circ} \mathrm{C}$ ). The pretreated feedstock slurry is subjected to different steps according to the composition of the LCB and the selected pretreatment method used. The slurry may be subjected to solid-liquid separation yielding a pentose (C5)-enriched effluent (liquor), derived from hemicellulose degradation, and a solid residue enriched in cellulose and lignin. The C5-containing liquor is sent to a dedicated fermentation tank, and the lignin-cellulose-containing solid is detoxified from inhibiting compounds and subjected first to enzymatic hydrolysis and then to hexose (C6) sugar fermentation. Alternatively, after pretreatment, the slurry can be directly hydrolyzed and fermented, in a process in which the fermentation of C5 sugars is performed downstream of C6 sugars. Although this process scheme enables fine tuning of process parameters for each step (i.e., $\mathrm{pH}$ and temperature), it also requires a higher number of reaction vessels, and the long process time make the whole procedure uncompetitive and economically unsustainable. Moreover, although $S$. cerevisiae performs very well in bioethanol production from starch, given the almost exclusive presence in the feedstocks of C6 sugars, in a lignocellulose-based biorefinery hemicellulose-derived C5 sugars cannot be efficiently utilized by this model yeast $[36,44]$. For this reason, engineered strains able to simultaneously ferment C5 and C6 sugars were developed and implemented in the process [6,44]. Alternatively, fermentation can be implemented by two microorganisms (e.g., S. cerevisiae and Scheffersomyces stipitis) simultaneously able to realize, when combined, mixed sugar fermentation [45]. The SHF process in which C5 and C6 sugars are co-fermented is generally referred to as separate 
hydrolysis and co-fermentation (SHCF) (Figure 4). Product recovery is achieved via selective evaporation and condensation of ethanol, exploiting its higher volatility compared to the fermenting slurry. The semi-solid residue at the end of the process (the whole stillage) is separated using a filter press to obtain a solid residue (the cake) and a liquid effluent referred to as thin stillage [44]. The cake is enriched in lignin (about 20 to $30 \%$ of the total mass) and can be burned on-site to generate vapor power to run the biorefinery (if the plant configuration enables it). Alternatively, it can be used as a soil amendment or disposed of with related costs [44].

Lignocellulosic Biomass

Size Reduction \& Pretreatment

Saccharification

C6 Fermentation

C5 Fermentation

SHF
Saccharification

C6 \& C5

Co-fermentation

SHCF

\section{Saccharification \& C6 Fermentation}
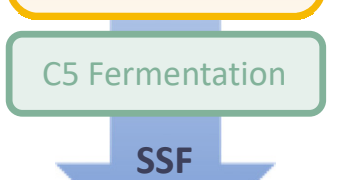

SSCF

In situ enzyme

production,

Saccharification,

\&

Co-fermentation

\section{CBP}

\section{Bioethanol}

Figure 4. Schematic representation of different step integration strategies.

Conversion of LCBs to ethanol is a stepwise process and, even though substantial effort has been put into optimizing each phase, the overall process is still complex and economically non-competitive, often being realized on a pilot or demonstrative scale [6]. Different process setups have been studied and proposed to integrate different steps into one. This strategy has the potential to reduce the initial capital investment and the operational costs, and may enhance the energy efficiency of the whole bioethanol plant [6,45]. For instance, fermentation can be performed alongside saccharification (SSF-Simultaneous Saccharification and Fermentation) (Figure 4). This method, compared to an SHF or SHCF model, presents key benefits for the overall production process and the critical challenges that remain to be addressed [36,46]. The main advantages of SSF include: (i) the fewer reaction vessels needed, (ii) the decreased process time, (iii) the minimized risk of contamination, (iv) the direct fermentation of sugars into ethanol, leading to (v) a decreased product-inhibition effect of sugars on hydrolytic enzymes, and vi) a favored xylose fermentation given the augmented xylose-to-glucose ratio [47]. However, current SSF processes must compromise reaction conditions to suboptimal $\mathrm{pH}$ and temperature values for enzymatic hydrolysis or fermentation. Although the optimal activity of commercial enzyme cocktails is achieved around $45-55^{\circ} \mathrm{C}$, fermentation using classical S. cerevisiae strains is performed at $30-37^{\circ} \mathrm{C}$. SSF carried out with mesophilic microorganisms compensates for the sub-optimal working temperature of hydrolytic enzymes with an augmented loading, thus increasing the overall biorefining costs [48]. Alternatively, SSF can be temporarily separated, even though the two phases (hydrolysis and fermentation) happen in the same vessel (i.e., spatially integrated). This is referred to as Semi-Simultaneous Saccharification and Fermentation (SSFS), and involves the implementation of a pre-hydrolysis phase before starting the fermentation. If correctly time-tuned, SSFS can ensure avoidance of enzyme product inhibition and higher ethanol yields than SHF processes [49,50], but remains a one-pot/two-phase process. Another possible setup is Simultaneous Saccharification and 
Co-Fermentation (SSFC), which represents a higher degree of process integration because fermentation of $\mathrm{C} 5$ and $\mathrm{C} 6$ sugars is carried out either by a (recombinant) strain capable of mixed sugar fermentation, or by co-culture of $\mathrm{C} 5$ and $\mathrm{C} 6$ fermenting microbes [51]. Finally, the highest process integration is achieved with a Consolidated BioProcess (CBP) (Figure 4), in which enzyme production, biomass hydrolysis, and fermentation occur in the same reaction vessel due to the direct activity of a microorganism or a microbial consortium [52]. Advantages of this process are the same as those of SS(C)F, with the additional benefit that commercial (hemi)-cellulases are no longer required because they are produced in situ by the selected microorganism(s). A small number of microbial candidates are capable of both hydrolysis and fermentation but are still not at a feasible industrial level, given the relatively low ethanol titer achieved, which represents the major drawback of this process at this stage of development. As a result, CBP is often realized through the co-culture of a hydrolysis-specialized microorganism and a fermenting partner, as described in the fermentation paragraph (see below).

\subsection{Advantages of Using Thermophiles in Biorefineries}

Thermophilic microorganisms thrive at temperatures up to $122^{\circ} \mathrm{C}$ and can be grouped based on their optimum growth temperature $\left(\mathrm{T}_{\mathrm{opt}}\right)$ as moderate thermophiles $\left(\mathrm{T}_{\mathrm{opt}}: 50-60{ }^{\circ} \mathrm{C}\right)$, extreme thermophiles ( $\left.\mathrm{T}_{\mathrm{opt}}: 60-80^{\circ} \mathrm{C}\right)$, and hyperthermophiles $\left(\mathrm{T}_{\mathrm{opt}}: 80-110^{\circ} \mathrm{C}\right)$. These microorganisms have attracted significant attention in recent decades as a source of industrially relevant enzymes [53,54]. In contrast to mesophilic enzymes, thermophilic ones have a higher unfolding (transition) temperature $\left(\mathrm{T}_{\mathrm{m}}\right)$ and a longer half-life at a selected high temperature as well as in the presence of organic solvents [55]. Therefore, thermophilic and thermostable enzymes can withstand harsh industrial conditions (i.e., extreme $\mathrm{pH}$, high temperature, long process time, presence of organic solvents, etc.), while ensuring the required standards of reproducibility. Considering that thermophiles are also a source of robust and effective carbohydrate degrading enzymes, their application in lignocellulosic ethanol biorefining has increasingly gained interest [56,57]. The use of thermophilic microorganisms and enzymes in $2 \mathrm{G}$ biorefineries may enable the whole production process to take place at high temperatures, allowing: (i) better substrate and product solubility, (ii) increased reaction rate, (iii) decreased amount of required enzyme [58], (iv) easier mixing (due to a drop in the viscosity of the medium), (v) reduced risk of contamination, (vi) easier product recovery [59], and (vii) reduced costs for cooling the reaction vessel.

Nevertheless, the mere substitution in $2 \mathrm{G}$ biorefineries of currently utilized enzymes and microorganisms with thermophilic counterparts (as often suggested in the literature $[48,60,61]$ ) would require redesigning the whole production process, which is unlikely to be welcomed by companies acting in this field. This would imply additional investments to adapt existing production plants to run at higher temperatures, and most likely require a different process setup. Hence, in this review, we propose to implement (not to substitute) thermophiles into currently operating $2 \mathrm{G}$ biorefineries by taking advantage of what we identify as "windows of opportunity". These latter are stages of the process in which the temperature is already high within the present setup. One such window of opportunity is available at the beginning of the $2 \mathrm{G}$ bioethanol production workflow, specifically, immediately after pretreatments that are run at high temperature. Downstream from these pretreatments, the temperature of the slurry is too high to start the saccharification with commercially available enzyme cocktails; therefore, a period of cooling elapses between the end of the pretreatment and the beginning of the saccharification phase. This "wasted" cooling time could be exploited to start pre-saccharification of the LCB by means of (hyper)-thermophilic enzymes that can withstand the high temperature of the pretreated slurry. Given that enzyme hydrolysis at high temperate would promote a better enzyme penetration within the LCB, in addition to an increased substrate solubility [62], the implementation of a pre-saccharification step would improve the release of fermentable sugars and, in turn, increase the overall ethanol yield. However, we are aware that designing an appropriate enzyme preparation for this specific phase may be challenging because 
physico-chemical conditions vary depending on the pretreatment method used. The second window of opportunity is represented by the saccharification step itself, which is already undertaken at moderate thermophilic conditions $\left(45-55^{\circ} \mathrm{C}\right)$. The substitution of currently employed mesophilic yeasts with fermenting thermophiles may represent a breakthrough in $2 \mathrm{G}$ bioethanol production because it would also enable a one-pot/one-phase SSF (also referred to as thermophilic SSF [48]). In contrast to classical SSF, this setup would not compromise on process temperature and/or timing of the different phases (see above), thus simplifying the overall process and gaining the benefit from the integration of the two phases (saccharification and fermentation). Notably, running the SSF process closer to the optimal working temperature of most commercially available enzymes (i.e., $45-55^{\circ} \mathrm{C}$ ) would require a smaller loading of hydrolytic enzymes to achieve a yield of fermentable sugars comparable (or superior) to that of a mesophilic SSF [48]. Moreover, the implementation of additional moderate thermophilic enzymes as supplements to commercial hydrolytic cocktails would allow further optimization of the efficiency of saccharification (see below). It should also be noted that running a thermophilic SSF would enable the integration of the product separation process (i.e., ethanol distillation) that could be carried out in a continuous manner [60]. This possibility, in addition to leading to a reduction in the total process time, would also avoid the accumulation of ethanol into the fermentation media that, in turn, would alleviate its toxicity towards the fermenting microorganisms. Due to all of the above-mentioned reasons, in the following paragraphs, each of the main steps involved in the conversion of LCBs to bioethanol is discussed to assess the possible integration of a plug-in thermophilic solution aimed at improving the profitability of the overall conversion process.

\section{Pretreatment of Lignocellulosic Biomasses}

Before fermentation, the LCB needs to be pretreated to separate its components and make them more accessible during the following enzymatic hydrolysis. Pretreatment of lignocellulose is a balancing act that has received significant research attention because it has a significant impact on the economic, technical, and environmental sustainability of $2 \mathrm{G}$ bioethanol production. The development of a versatile technology that can reach appropriate levels of effectiveness regardless of the initial raw material remains a major challenge, limiting the flexibility of a given plant to process different feedstocks [38]. Moreover, the development of an eco-friendly and economically advantageous treatment, in which corrosive chemicals are not used, is of high interest. The pretreatment processes of LCBs can generally be categorized into physical, chemical, physico-chemical, biological, or a combination thereof, as schematized in Figure 3. A comprehensive analysis of the different pretreatment methods is beyond the scope of this review and the reader is referred to the literature for further details [63-66]. The focus is instead placed on biological pretreatment and the advantages of employing thermophilic microorganisms.

The biological pretreatment deploys microorganisms and their enzymes for selective delignification of lignocellulosic residues with low-energy demand, mild environmental conditions, and minimal waste production. Some of the disadvantages of biological pretreatment that make it less suitable for industrial applications include: (i) long residence time (10-14 days), (ii) very slow rate of hydrolysis, (iii) extremely limiting growth conditions, and iv) the need for a large bioreactor. Moreover, a fraction of the carbohydrate contained in the biomass is used by the microorganisms, potentially affecting the yield of the overall process. To date, biological pretreatment has been exploited as a preliminary step in combination with other pretreatment methods or as a standalone process if the biomass has a low lignin content [67].

Fungi primarily degrade lignin and hemicellulose, and partially cellulose, at mild reaction conditions and low temperatures $\left(20-30{ }^{\circ} \mathrm{C}\right)$ [68]. White- and soft-rot fungi attack both cellulose and lignin, whereas brown-rot fungi are specialized in cellulose degradation. Fungi degrade lignin by secreting enzymes referred to as "ligninases", including two main ligninolytic families: (i) phenol oxidase (laccase) and (ii) peroxidases 
(lignin and manganese) [69]. A diverse range of white-rot fungi, such as Pleurotus ostreatus, Ceriporia lacerata, Cyathus stercoreus, Ceriporiopsis subvermispora, Pycnoporus cinnabarinus, and Phanerochaete chrysosporium, have been investigated in various biomasses [70]. Moreover, Phanerochaete chrysosporium, which has a higher optimum temperature $\left(40^{\circ} \mathrm{C}\right)$ and can grow at up to $50{ }^{\circ} \mathrm{C}$, has been reported to break down lignin up to $3 \mathrm{~g}$ of lignin/g cell per day [18]. However, although the implementation of these microorganisms (or of their enzymes) may significantly simplify the removal of lignin, the end product formation is not efficient [18]. Several parameters, such as the concentration of the microbial inoculum, the $\mathrm{pH}$, the aeration rate, and the time and temperature of incubation, affect the overall yield of the process, which is still not competitive, and it is preferably used in combination with other pretreatment methods. Mutagenesis aiming to improve enzymatic secretion is one of the strategies to implement the biological pretreatment. For instance, an improvement was observed in the cellulolytic activity of T. reesei QM6 using different mutagenesis techniques, including UV light and chemicals, resulting in the mutant QM 9414 with higher filter paper activity (FPA) [71]. The T. reesei RUT-C30 mutant can produce 4-5 times more cellulase compared to the wild-type strain (QM 6a). In another study, the thermostable endo-1,4$\beta$-xylanase (XynII) mutants from T. reesei were further mutagenized to resist inactivation at high $\mathrm{pH}$ by using site-directed mutagenesis. All mutants were resistant to thermal inactivation at alkaline $\mathrm{pH}$ values. For example, thermotolerance for one mutant (P9) was increased by approximately $4-5^{\circ} \mathrm{C}($ at $\mathrm{pH}$ 9), resulting in better activity in sulfate pulp bleaching compared to the reference strain [72].

In nature, lignin is deconstructed by the synergistic efforts of microbial communities rather than isolate microorganisms, including diverse fungi and bacteria, belonging to several genera, that produce a variety of cellulolytic and hemicellulolytic enzymes under aerobic and anaerobic conditions. Therefore, the strategy of studying the microbial community rather than a single strain may provide a broader comprehension of the process of lignin deconstruction. Moreover, this would offer means to improve the hydrolysis of lignocellulosic residues by overcoming the problems of feedback regulation and metabolite repression that affect single strains. For instance, Liu et al. (2009) [73] reported a lignocellulolytic microbial consortium from successive enrichment cultures that completely degraded filter paper at $50{ }^{\circ} \mathrm{C}$ after $48 \mathrm{~h}$ of incubation and degraded $99.0 \%$ of rice straw at $50{ }^{\circ} \mathrm{C}$ after 8-10 days. Wongwilaiwalin et al. (2010) [74] isolated and characterized a stable thermophilic lignocellulolytic microbial consortium highly active in cellulosic biomass degradation from a high-temperature sugarcane bagasse compost. The consortium was structurally stable with the co-existence of eight major microbes, comprising anaerobic bacterial genera Clostridium and Thermoanaerobacterium, in addition to an aerobic/facultative anaerobic Rhodocyclaceae bacterium, bacilli, and uncultured bacteria. This consortium showed efficient degradation activity on potential biorefinery cellulosic substrates, including bagasse, rice straw, corn stover, and industrial eucalyptus pulp sludge. In another study, Wang et al. (2011) [75] isolated the WCS- 6 community, consisting of at least 14 aerobic and anaerobic bacteria, and able to degrade $99.0 \%$ of filter paper, $76.9 \%$ of cotton, and $81.3 \%$ of rice straw within 3 days at $50{ }^{\circ} \mathrm{C}$ under static conditions. Other lignocellulose-degrading consortia have been described in [76,77], but none of these can efficiently degrade biomass in a short timeframe (less than 3 days). Investigation of natural microbial communities using culture-independent approaches (e.g., meta-omics techniques) may also be crucial to the development of efficient industrial processes involving the use of ligninolytic feedstock. The use of metagenomic approaches may extend the research to unculturable microorganisms, thus broadening the enzyme availability for lignocellulosic degradation [78]. For example, the ligninolytic potential of several bacteria, including new non-cultivable clades such as Caulobacteraceae, Solirubrobacterales, and Cystobacteraceae, was evidenced with metagenomic methods, and the identification of a set of potential bacterial genes for auxiliary activities involved in the degradation of lignin and other components of the plant cell wall. The development of these complementary approaches is crucial to achieve satisfactory yields. Moreover, the aforementioned microorganisms can be used as a reservoir to 
isolate thermophilic and hyperthermophilic enzymes which can be applied between the pretreatment and saccharification phase, in a pre-saccharification step, when the biomass is still at high temperature, to maximize the accessibility of cellulose and increase the yield of the overall process. In an enrichment experiment at temperatures above $90^{\circ} \mathrm{C}$, utilizing crystalline cellulose as a carbon source, several interesting hyperthermophilic cellulases were characterized from the isolated archaeal consortium [79]. Among these, cellulase EBI-244 showcased optimal activity around $109^{\circ} \mathrm{C}$, in addition to halotolerance, resistance to ionic and non-ionic detergents, and activity in ionic liquids [79]; these are all desirable characteristics for enzymes to be used downstream of the pretreatments. Hyperthermophilic xylanases are also described in the literature. Some of these are produced by microorganisms belonging to the genera Acidothermus and Thermotoga and have shown a half-life of up to $2 \mathrm{~h}$ at $90^{\circ} \mathrm{C}[80,81]$. Unfortunately, despite the availability of numerous enzymes active at temperatures above $90^{\circ} \mathrm{C}$ on model substrates [82], few examples of their use on industrially relevant substrates are available in the literature. Therefore, it would be very useful if future works focused on testing the catalytic activity of hyperthermophilic enzymes on industrially relevant biomasses after pretreatment. On a more general note, further research in the field of LCBs pretreatment is needed to achieve a greener and less cost-intensive approach. For this purpose, delignification on behalf of extremozymes could be an attractive choice for future implementations.

\section{Enzymatic Hydrolysis}

Given the chemical complexity and heterogeneity of LCBs, the synergistic action of a wide range of enzymes is required to convert their polysaccharides into fermentable sugars. The outcome of saccharification is highly influenced by the chemical composition of the original feedstock, which is variable according to the source material and the selected pretreatment method [83-85]. In general, hardwood species have higher xylan and lower mannan content than softwoods, thus requiring different cocktail formulations to achieve optimal saccharification [86-90]. Currently used commercial cocktails are mainly based on fungal secretome(s) (i.e., secreted enzymes) from Trichoderma reesei. Despite their mesophilic origin, these fungal-derived enzymatic cocktails show optimal activity around $45-55{ }^{\circ} \mathrm{C}$. However, an important limitation is represented by their relatively rapid inactivation over time. In this regard, more thermostable enzymes would offer greater robustness at high temperatures, extreme $\mathrm{pH}$ values, and resistance towards organic solvents, thus improving the hydrolysis efficiency of LCBs [58]. For this reason, research has been focused on the study of new thermostable enzymes that could improve the performance of commercial cocktails used for the saccharification of LCBs, by supplementing or replacing some of their components. In this paragraph, we overview recent studies in which the addition of thermophilic and thermostable enzymes clearly showed advantages in hydrolyzing industrially relevant LCBs, such as sugarcane bagasse, corncob, or rice straw, even when tested at optimal temperatures of commercial cocktails $\left(45-55^{\circ} \mathrm{C}\right)$ (Table 1$)$.

Secretome(s) from $T$. reesei are generally rich in cellulases but lack $\beta$-glucosidases. Commercial cocktails have often combined secretome(s) from T. reesei with isolated enzymes or secretome(s) from other species, such as Aspergillus niger, which is richer in $\beta$-glucosidase, thus avoiding/alleviating product inhibition of cellulases by cellobiose [91]. For instance, a thermostable endo-1,4- $\beta$-glucanase (Af-EGL7) from Aspergillus fumigatus EGL7, as a supplement to Celluclast ${ }^{\circledR} 1.5 \mathrm{~L}$, showed an increase in released reducing sugars of $128 \%$ and $80 \%$ from corncob and rice straw, respectively [92]. Af-EGL7 exhibited no activity loss after $72 \mathrm{~h}$ of incubation at $55^{\circ} \mathrm{C}, 3-8 \mathrm{pH}$ range, making this enzyme suitable for industrial processes over a broad $\mathrm{pH}$ range. A thermostable endo $\beta-1,4-\mathrm{D}$-glucanase from Trichoderma harzianum HZN11 improved the saccharification of sweet sorghum and sugarcane bagasse, in addition to a commercial cellulase from Trichoderma spp., in particular, increasing the sugar yield by $54 \%$ and $21 \%$, respectively [93]. The enzyme also showed more than $75 \%$ of relative activity in most of the organic solvents such as glycerol, ethanol, methanol, acetone, propanol, petroleum ether, isopropanol, benzene, cyclohexane, 
hexane, butanol, and toluene, even at 30\% concentration. A bifunctional cellobiohydrolasexylanase $\mathrm{CtCel7}$ from Chaetomium thermophilum was identified and characterized, showing a synergistic effect with a commercial cocktail from T. reesei (Cellulase, Sigma-Aldrich) for the hydrolysis of pretreated wheat straw, leading to an increase of $61 \%$ of total released reducing sugars compared to the control [94]. CtCel7 displayed stability at $60{ }^{\circ} \mathrm{C}(90 \%$ residual activity after $180 \mathrm{~min}$ ), and it was shown that its catalytic activity was not influenced by the addition of many metal ions or other chemicals that generally inhibit the catalytic activity of cellulases. Moreover, a beneficial effect of Tween-20, Triton X-100, and PEG-600 on CtCel7 activity was highlighted. A $\beta$-glucosidase from Humicola grisea var. thermoidea increased the saccharification of sugarcane bagasse by $50 \%$ when $0.1 \mathrm{U}$ of pure or crude enzymes was added to $10 \mathrm{FPU}$ of T. reesei cellulases [95]. $\beta$-glucosidase TN0602 from Thermotoga naphthophila RUK-10 increased glucose release rates when added to a commercial cellulase from T. reesei (ATCC26921 Solid, Sigma-Aldrich) in the hydrolysis of microcrystalline cellulose, untreated corn straw, and steam-exploded corn straw by 15.82 , 30.62 , and $35.21 \%$, respectively [96].

Regarding new thermostable hemicellulases, the combination of Accellerase 1500 with a cocktail of recombinant hemicellulases composed of endoxylanase (HXYN2) and $\beta$-xylosidase (HXYLA) from Humicola grisea var thermoidea and $\alpha$-L-arabinofuranosidase (AFB3) from Penicillium pupurogenum enhanced the glucose yield from steam-exploded sugarcane bagasse hydrolysis by $14.6 \%$. This effect was even more evident (up to $50 \%$ ) in two step-sequential hydrolysis, in which biomass was treated first with hemicellulases and then with commercial cellulases [97]. Similarly, in another study, the synergism between the two xylanases XynZ-C from Clostridium thermocellum and Xyn11A from Thermobifida fusca led to a two-fold increase in the concentration of reducing sugars from pre-treated bagasse hydrolysis, in addition to a commercial cellulase from T. reesei (Sigma-Aldrich) [98]. Another example is given by xylanase TcXyn10A from Thermobacillus composti, which was characterized by a $60 \%$ of relative activity after $8 \mathrm{~h}$ of incubation at $65{ }^{\circ} \mathrm{C}$. Moreover, TcXyn10A improved the efficiency of pretreated lignocellulosic biomass hydrolysis when added to the Accellerase ${ }^{\circledR} 1500$ cocktail, leading to a 15.35 and $4.38 \%$ increased release in xylose and glucose, respectively. Moreover, its resistance toward 10\% (v/v) ethanol is noteworthy because it makes this enzyme particularly suitable for one-pot/one-phase thermophilic SSF (see above) [99]. Regarding other types of hemicellulases, the addition of the mannanase MtMan26A from C. thermophilum to the commercial cocktails Celluclast ${ }^{\circledR} 1.5 \mathrm{~L}$ and Novozyme ${ }^{\circledR} 188$ (no longer commercially available) resulted in enhanced enzymatic hydrolysis of pretreated beechwood sawdust. In particular, the hydrolytic performance of both these enzymatic blends was improved, as indicated by an increase of 13 and $12 \%$, in the release total reducing sugars and glucose, respectively [100]. Among lignocellulolytic enzymes, lytic polysaccharide monooxygenases (LPMOs) are the most recently discovered [101,102]. In particular, LPMOs are copper-dependent monooxygenases that catalyze the hydroxylation of either carbon $\mathrm{C} 1$ or $\mathrm{C} 4$ of a glycosidic bond, thus making cellulose fibers more accessible to the action of other hydrolytic enzymes (Figure 2) [103]. Two novel LPMOs from thermophilic fungi Scytalidium thermophilum (PMO9D_SCYTH) and Malbranchea cinnamomea (PMO9D_MALCI), highly thermostable at $60^{\circ} \mathrm{C}$ and $50^{\circ} \mathrm{C}$, respectively, have been tested in addition to commercial Cellic CTec2 in a ratio of 9:1 on acid and alkali pretreated bagasse and rice straw, enhancing the release of reducing sugars by $20-30 \%$ compared to Cellic CTec 2 alone [104]. Nevertheless, the consequence of using such oxidative enzymes on the process configuration should be considered. For instance, as shown by Peciulyte et al. (2018) [105], it is very important to consider the effect of abiotic reactions at increased process temperature. Moreover, a significant factor influencing the saccharification efficiency is the oxidative inactivation of the hydrolytic enzymes. In this regard, it has been shown that cellulase mixtures can be protected from inactivation by the addition of catalase [106].

In addition to the discovery of novel enzymes from thermophilic microorganisms, another strategy to achieve improved performances of hydrolytic cocktails at high tem- 
peratures may also be the thermostabilization of well-performing mesophilic enzymes by (semi)-rational design or directed evolution strategies. In rational design approaches, a set of mutations is predicted to be beneficial for a given property, such as thermostability. This prediction is made according to sequence alignment with known homologous thermostable proteins or by tertiary structure analysis, which can allow us to identify the stabilizing positions to mutate [107-111]. This approach is increasingly being assisted by several computational design methodologies such as FRESCO (Framework for Rapid Enzyme Stabilization by Computational libraries [112], PROSS (Protein Repair One Stop Shop) [113], and CNA (Constraint Network Analysis) [114], which can be used to predict structures with increased stability. These tools provide in-depth analysis to predict "small but smart" mutant libraries with a high chance of tailoring the desired enzymatic properties of cellulase cocktails, such as thermostability. By comparison, the directed evolution approach consists of a reiterative process of random mutagenesis [115-118] and high throughput screening that is used to mimic natural selection, with the advantage of not requiring an in-depth understanding of protein structure to improve the desired enzyme property. Both these approaches have also been used with success to improve the thermostability of lignocellulolytic enzymes. For instance, computational methods were used to set up a library of mutations to improve the stability of endoglucanase I (EGI) from T. reesei, resulting in a $25 \%$ increase in thermostability at $65^{\circ} \mathrm{C}$ [119], whereas Cel7A cellobiohydrolase I from $T$. reesei was improved by directed evolution. In this work, a Cel7A variant (FCA398), containing 18 mutated sites, was isolated and exhibited a $10.4^{\circ} \mathrm{C}$ increase in $\mathrm{Tm}$ and a 44-fold greater half-life compared with the wild-type enzyme [120]. Although the above-mentioned studies demonstrate the advantages of applying thermophilic enzymes in addition to commercial preparations, their actual implementation is a slow process that requires further investigations to optimize their heterologous expression [121], and to define the most appropriate cocktail composition [122]. 
Table 1. Examples of thermophilic enzymes implementation in commercial cellulolytic enzyme blends.

\begin{tabular}{|c|c|c|c|c|c|c|}
\hline Enzyme [Reference] & Microorganism & $\mathrm{T}_{\text {opt }}\left({ }^{\circ} \mathrm{C}\right)$ & $\mathrm{pH}_{\mathrm{opt}}$ & Thermal Stability (Activity \%) & Substrate & Result \\
\hline $\begin{array}{l}\text { Endo-1,4- } \beta \text {-glucanaseAf- } \\
\text { EGL7 [92] }\end{array}$ & Aspergillus fumigatus & 55 & 5 & $61 \%$ after $24 \mathrm{~h}$ at $60^{\circ} \mathrm{C}$ & $\begin{array}{l}\text { Corncob } \\
\text { Rice straw }\end{array}$ & $\begin{array}{c}\text { The addition of } 10 \mu \mathrm{g} \text { of Af-EGL7 to } 0.009 \mathrm{FPU} \text { of } \\
\text { Celluclast }^{\circledR} 1.5 \mathrm{~L} \text { increased the release of reducing sugars } \\
\text { by } 128 \% \text { after } 72 \mathrm{~h}\left(55^{\circ} \mathrm{C}, \mathrm{pH} 5\right) \\
\text { The addition of } 10 \mu \mathrm{g} \text { of Af-EGL7 to } 0.009 \text { FPU of } \\
\text { Celluclast }{ }^{\circledR} 1.5 \mathrm{~L} \text { increased the release of reducing sugars } \\
\text { by } 80 \% \text { after } 72 \mathrm{~h}\left(55^{\circ} \mathrm{C}, \mathrm{pH} 5\right)\end{array}$ \\
\hline $\begin{array}{c}\text { Endo- } \beta-1,4-\mathrm{D}-\text { glucanase } \\
{[93]}\end{array}$ & $\begin{array}{l}\text { Trichoderma harzianum } \\
\text { HZN11 }\end{array}$ & 60 & 5.5 & $66 \%$ after $3 \mathrm{~h}$ at $65^{\circ} \mathrm{C}$ & $\begin{array}{l}\text { Alkali pretreated sweet } \\
\text { sorghum } \\
\text { Sugarcane bagasse }\end{array}$ & $\begin{array}{c}53 \mathrm{U} / \mathrm{g} \text { mixed with } 9 \mathrm{FP} \mathrm{U} / \mathrm{mL} \text { of commercial } \\
\text { Trichoderma sps. increased the release of reducing sugars } \\
\text { by } 54 \% \text { after } 48 \mathrm{~h}\left(40^{\circ} \mathrm{C} \text {, pH } 5.5\right) \\
53 \mathrm{U} / \mathrm{g} \text { mixed with } 9 \mathrm{FP} \mathrm{U} / \mathrm{mL} \text { of commercial } \\
\text { Trichoderma sps. increased the release of reducing sugars } \\
\text { by } 21 \% \text { after } 48 \mathrm{~h}\left(40^{\circ} \mathrm{C} \text {, pH } 5.5\right)\end{array}$ \\
\hline $\begin{array}{l}\text { Cellobiohydrolase CtCel7 } \\
{[94]}\end{array}$ & Chaetomium thermophilum & 60 & 4 & $90 \%$ after $3 \mathrm{~h}$ at $60^{\circ} \mathrm{C}$ & Pretreated wheat straw & $\begin{array}{l}\text { The addition of CtCel7 to Sigma-Aldrich cellulase } \\
\text { cocktail in 1:1 ratio increased the release of reducing } \\
\text { sugars by } 63 \% \text { after } 8 \mathrm{~h}\left(60^{\circ} \mathrm{C}, \mathrm{pH} 4\right) \text {. }\end{array}$ \\
\hline$\beta$-glucosidase [95] & $\begin{array}{l}\text { Humicola grisea var. } \\
\text { thermoidea }\end{array}$ & 50 & $6-7$ & $\begin{array}{l}50 \% \text { after } 7 \text { and } 14 \text { min at } 60{ }^{\circ} \mathrm{C} \\
\text { in absence or presence of } \\
50 \mathrm{mM} \text { glucose }\end{array}$ & Sugarcane bagasse & $\begin{array}{l}\text { The addition of } 0.1 \mathrm{U} \text { of purified or crude } \beta \text {-glucosidase } \\
\text { to } 10 \text { FPU T. reesei cellulases increased the } \\
\text { saccharification by } 50 \% \text {. }\left(50^{\circ} \mathrm{C}, \mathrm{pH} 5\right)\end{array}$ \\
\hline $\begin{array}{l}\beta \text {-glucosidase TN0602 } \\
{[96]}\end{array}$ & $\begin{array}{l}\text { Thermotoga naphthophila } \\
\text { RUK-10 }\end{array}$ & 75 & 6 & $50 \%$ after $3 \mathrm{~h}$ at $90^{\circ} \mathrm{C}[123]$ & Corn straw & $\begin{array}{l}\text { A maximum increase in released glucose of } 30.62 \% \text { when } \\
0.5 \mathrm{U} / \mathrm{mL} \text { pf addition TN0602 were added to } 0.75 \mathrm{U} / \mathrm{mL} \\
\text { of commercial cellulase from } T \text {. reesei }\left(50^{\circ} \mathrm{C}, \mathrm{pH} 5\right)\end{array}$ \\
\hline $\begin{array}{c}\beta \text {-xylosidase (HXYLA) } \\
{[97]}\end{array}$ & & 50 & 7 & $20 \%$ after $48 \mathrm{~h}$ at $50{ }^{\circ} \mathrm{C}$ & $\begin{array}{l}\text { Steam-exploded corn } \\
\text { straw }\end{array}$ & HXYLA and $0.32 \mathrm{U} / \mathrm{g}$ ABF3) to $5 \mathrm{FPU} / \mathrm{g}$ Accellerase \\
\hline $\begin{array}{l}\alpha \text {-L-arabinofuranosidase } \\
\text { (AFB3) [97] }\end{array}$ & Penicillium pupurogenum & 50 & 5 & $25 \%$ after $48 \mathrm{~h}$ at $50{ }^{\circ} \mathrm{C}$ & & $\begin{array}{c}1500 \text { enhanced the glucose yield by } 14.6 \% \text { in } \\
\text { simultaneous reaction and by } 50 \% \text { in sequential } \\
\text { reactions after } 48 \mathrm{~h},\left(50^{\circ} \mathrm{C}, \mathrm{pH} 5\right)\end{array}$ \\
\hline XynZ-C and Xyn11A [98] & $\begin{array}{l}\text { Clostridium thermocellum } \\
\text { Thermobifida fusca }\end{array}$ & 75 & 7 & $\begin{array}{l}96 \% \text { after } 18 \mathrm{~h} \text { at } 75^{\circ} \mathrm{C} \text { in } 10 \% \\
\text { glycerol [124] }\end{array}$ & Pretreated bagasse & $\begin{array}{l}\text { 2-fold increase in the concentration of reducing sugars, } \\
\text { when both xylanases, were added to T. reesei cellulase in } \\
50: 50 \text { ratio }\left(50^{\circ} \mathrm{C}, \mathrm{pH} 6\right)\end{array}$ \\
\hline Xylanase (TcXyn10A) [99] & Thermobacillus compost $i$ & 65 & $6-8$ & $40 \%$ after $8 \mathrm{~h}$ at $65^{\circ} \mathrm{C}$ & Sugarcane bagasse & $\begin{array}{l}\text { Improvement of hydrolysis Accellerase }{ }^{\circledR} 1500 \text { cocktail } \\
\text { hydrolysis by } 15.35 \% \text { increase in xylose release and } \\
4.38 \% \text { glucose release after } 24 \mathrm{~h} \text { in } 1: 1 \text { ratio }\left(50^{\circ} \mathrm{C} \mathrm{pH} 5\right) \\
\text { Release of total reducing sugars and glucose improved }\end{array}$ \\
\hline $\begin{array}{l}\text { Endo- } \beta \text {-mannanase } \\
\text { MtMan26A [100] }\end{array}$ & Myceliophthora thermophila & 60 & 6 & $50 \%$ after $14.4 \mathrm{~h}$ at $60^{\circ} \mathrm{C}$ & $\begin{array}{l}\text { Pretreated beechwood } \\
\text { sawdust }\end{array}$ & $\begin{array}{l}\text { Release of total reducing sugars and glucose improved } \\
\text { by } 13 \text { and } 12 \% \text {, as a supplement to Celluclast }{ }^{\circledR} 1.5 \mathrm{~L} \text { and } \\
\text { Novozyme }{ }^{\circledR} 188 \text { in } 1: 1 \text { ratio }\left(50^{\circ} \mathrm{C} \text { pH } 5\right)\end{array}$ \\
\hline
\end{tabular}


Table 1. Cont.

\begin{tabular}{|c|c|c|c|c|c|c|}
\hline Enzyme [Reference] & Microorganism & $\mathrm{T}_{\text {opt }}\left({ }^{\circ} \mathrm{C}\right)$ & $\mathrm{pH}_{\text {opt }}$ & Thermal Stability (Activity \%) & Substrate & Result \\
\hline $\begin{array}{c}\text { LPMO PMO9D_SCYTH } \\
\text { [104] }\end{array}$ & Scytalidium thermophilum & 60 & 7 & $50 \%$ after 60.58 h at $60^{\circ} \mathrm{C}$ & $\begin{array}{c}\text { Bagasse } \\
\text { Rice straw }\end{array}$ & $\begin{array}{c}18.9 \text { and } 17.5 \% \text { yield increase from acid or alkali-treated } \\
\text { bagasse respectively } \\
\left.\text { (Cellic CTec2, } 9: 1 \text { ratio, } 50^{\circ} \mathrm{C} \mathrm{pH} 5\right) \\
28.7 \text { and } 22.1 \% \text { yield increase from acid or alkali-treated } \\
\text { rice straw respectively } \\
\left.\text { (Cellic CTec2, } 9: 1 \text { ratio, } 50^{\circ} \mathrm{C} \text { pH } 5\right)\end{array}$ \\
\hline $\begin{array}{c}\text { LPMO PMO9D_MALCI } \\
\text { [104] }\end{array}$ & Malbranchea cinnamomea & 50 & 9 & 50 after $144 \mathrm{~h}$ at $50^{\circ} \mathrm{C}$ & $\begin{array}{c}\text { Bagasse } \\
\text { Rice straw }\end{array}$ & $\begin{array}{c}21.3 \text { and } 23.6 \% \text { yield increase from acid or alkali-treated } \\
\text { bagasse respectively } \\
\left.\text { (Cellic CTec2, 9:1 ratio, } 50{ }^{\circ} \mathrm{C} \mathrm{pH} 5\right) \\
28.8 \text { and 13.6\% yield increase from acid or alkali } \\
\text { respectively } \\
\text { (Cellic CTec2, 9:1 ratio, } 50^{\circ} \mathrm{C} \mathrm{pH} \mathrm{5)}\end{array}$ \\
\hline
\end{tabular}




\section{Thermophilic Fermentation}

To improve its economic feasibility, $2 \mathrm{G}$ bioethanol production must make use of all lignocellulose-derived sugars, including cellobiose, xylose, and arabinose. Moreover, the possibility to achieve an SSF process configuration has gathered significant interest, given its associated benefits, among which the most prominent are: (i) energy savings due to reduced cooling costs, (ii) higher saccharification and fermentation rates, (iii) continuous ethanol removal under low working pressure, and (iv) reduced contamination risk [125]. Traditional large-scale ethanol biorefineries make use of S. cerevisiae, which cannot ferment the whole sugar spectrum obtained from the hydrolysis of lignocellulose. Although a large amount of effort is undertaken to engineer S. cerevisiae for C5 sugar utilization [126], it remains a mesophile organism and, as such, its optimal fermentation temperature $\left(30-35^{\circ} \mathrm{C}\right)$ represents a limit for the achievement of a proper (one-pot/onephase) SSF.

Kluyveromyces marxianus is a thermotolerant ascomycetous yeast, which can grow at temperatures up to $52{ }^{\circ} \mathrm{C}$ and can ferment a broad range of substrates (e.g., inulin, lactose, cellobiose, xylose, and arabinose) to ethanol [125,127]. Biotechnological interest in this non-conventional yeast has notably increased during the past decade as a valuable platform for the production of ethanol and other chemicals, also considering that it is regarded as safe for food and pharmaceutical applications [125,128-130]. As it concerns the use of this thermotolerant yeast in the context of $2 \mathrm{G}$ ethanol production, Table 2 reports some recent examples of fermentations carried out using K. marxianus at temperatures equal to or higher than $40^{\circ} \mathrm{C}$ in an SSF configuration. In recent work, it was shown that K. marxianus has the potentiality to substitute $S$. cerevisiae as a high-temperature tolerant (i.e., $48^{\circ} \mathrm{C}$ ) and fermenting microorganism in the Brazilian context of bioethanol production from sugarcane bagasse [131]. Moreover, da Silva and colleagues (2018) compared SSF ethanol production from pretreated carnauba straw residues using either K. marxianus or $S$. cerevisiae at 35,40 , and $45^{\circ} \mathrm{C}$. These authors reported that fermentation carried out at $45^{\circ} \mathrm{C}$ by K. marxianus resulted in a higher ethanol titer compared to $S$. cerevisiae at its optimal fermentation temperature (i.e., $35^{\circ} \mathrm{C}$ ). In three fermentation tests of four, Guilherme et al. (2019) [132] showed that K. marxianus had a greater conversion yield than S. cerevisiae when converting sugars to ethanol from differently pretreated sugarcane bagasse in an SSF process. Moreover, Yan et al. (2015) [133] reported that K. marxianus K213 achieved a 1.78-fold higher ethanol yield (compared to that of a strain of S. cerevisiae) when used for one-pot/one-phase SSF fermentation of $\mathrm{NaOH} / \mathrm{H}_{2} \mathrm{O}_{2}$-pretreated water hyacinth. Based on the data summarized above and in Table $2, K$. marxianus is reportedly performing comparably to or better than S. cerevisiae. Therefore, we propose that more effort should be made to implement the use of $K$. marxianus (or other thermophiles) instead of $S$. cerevisiae to establish a one-pot/one-phase SSF process at an industrial scale for the conversion of lignocellulose into ethanol. This would finally allow $2 \mathrm{G}$ biorefineries to approach full exploitation of the benefits of an SSF configuration, which is currently under-valorized given the current temperature compromise imposed using mesophilic yeasts (see above). However, the optimal SSF process temperature of $50{ }^{\circ} \mathrm{C}$ remains unmet by both currently employed mesophilic and potentially applicable thermotolerant yeasts.

In this context, it is worth mentioning that among ethanologenic thermophilic microorganisms, several bacteria, belonging to different genera, showcase optimal growth temperatures at or above the activity optimum (i.e., $45-55^{\circ} \mathrm{C}$ ) of commercial enzyme cocktails currently used for saccharification. Moreover, some of these can hydrolyze cellulose and/or hemicellulose and ferment the deriving sugars (mainly) to ethanol, thus representing a valuable alternative to the currently employed mesophilic workhorses. Overall, these features not only make these thermophiles interesting in respect to the possibility to achieve an uncompromised one-pot/one-phase SSF process, but also to pave the way for a CBP biorefinery architecture. Clostridium thermocellum, due to its ability to solubilize lignocellulose with a high conversion rate, is among the most characterized cellulolytic and 
ethanol-producing thermophiles [134]. Therefore, it is considered as a candidate organism for the establishment of a CBP for the conversion of lignocellulose to biofuels [135]. C. thermocellum is a Gram-positive, rod-shaped, obligate anaerobic bacterium, whose cellulolytic activity is due to the cell-wall-bound multi hydrolytic enzyme complexes (i.e., the cellulosome) that it secretes in addition to individual free enzymes [134,136]. Notably, its hydrolytic activity is often compared to that of commercial enzyme blends $[137,138]$. Moreover, in addition to ethanol production, members of the genus Clostridium are employed in a number of biorefinery applications, as widely reviewed in $[139,140]$. Regarding lignocellulosic biomass utilization, despite being able to degrade hemicellulose, $C$. thermocellum cannot utilize C5 sugars in its fermentative metabolism [134,141], which can also have an inhibiting effect [138]. Xiong et al. (2018) [142] recently engineered C. thermocellum with the genes $x y l A$ and $x y l B$ from Thermoanaerobacter ethanolicus to enable xylose co-utilization with C6 cellulose-derived sugars. However, practical application of the engineered strain still requires some study to realize effective breakdown and co-fermentation of both cellulose and hemicellulose [142]. Moreover, despite the numbers of engineering efforts made on this organism, which are summarized in [143], the ethanol titer achieved by $C$. thermocellum remains insufficient to meet those of traditional fermenting organisms (e.g., S. cerevisiae and Z. mobilis). Although genetic advancements are being achieved, C. thermocellum is frequently employed as a lignocellulose-solubilizing agent in co-culture with ethanologenic partners capable of hemicellulose sugar utilization. Some fermentation examples involving $C$. thermocellum on industrially relevant feedstocks are listed in Table 2. Members of the genera Thermoanaerobacterium and Thermoanaerobacter make the perfect fermentation companions because they are anaerobic xylanolytic thermophiles that can withstand high cultivation temperatures (55-65 and $65-75^{\circ} \mathrm{C}$, respectively) [144-146]. Thermoanaerobacterium saccharolyticum, the main represented and studied example of its genus in the framework of ethanol biorefineries, is capable of fermenting xylan and the main sugars composing lignocellulose; however, it cannot ferment cellulose [137,147]. Metabolic engineering aimed to remove fermentation pathways that produce by-products, thus enabling the development of a strain that can produce ethanol at $90 \%$ of its theoretical yield. However, if supplied with an industrially relevant feedstock, such as pretreated hardwood, the inhibitory effect of the released compounds lowers the yield by around $76 \%$ with a final ethanol titer of about $30 \mathrm{~g} / \mathrm{L}$ [147]. Despite the breakthrough in genetic advancement based on this bacterium, the discovery that commercial enzyme blends become inactivated at low redox conditions (reached during fermentation) forced studies on these microorganisms to focus on an expression and secretion approach of heterologous cellulases $[147,148]$. Unfortunately, the expression levels of these enzymes were inadequate [147]. Thus, the co-culture of T. saccharolyticum with other thermophilic anaerobic bacteria (e.g., C. thermocellum) remains a relevant strategy [149].

Thermoanaerobacter ethanolicus and Thermoanaerobacter mathranii are the main representatives of their genus, which has been extensively studied because its species show the highest ethanol yields from sugar exhibited by a thermophile [146]. Reports of the fermentation performance with industrial relevant feedstocks and lignocellulose-mimicking substrates available in the literature, although not recent, are listed in [146]. Regarding thermophiles ethanol production from industrially relevant feedstocks, Pang et al. $(2018,2019)[150,151]$ realized fermentation of untreated corn straw and salix to ethanol through a CBP co-culture of $\mathrm{C}$. thermocellum and Thermoanaerobacterium thermosaccharolyticum at $55{ }^{\circ} \mathrm{C}$ achieving ethanol yields around $11 \%$ (respectively corresponding to 0.45 and $0.2 \mathrm{~g} / \mathrm{L}$ ). Bu et al. (2017) [152] reported an ethanol titer around $0.5 \mathrm{~g} / \mathrm{L}$ deriving from the co-fermentation of sugarcane bagasse by $\mathrm{C}$. thermocellum and Thermoanaerobacterium aotearoense in a $\mathrm{CaCO}_{3}$ buffered medium. Singh et al. (2021) [153] proposed direct valorization of the slurry resulting from dilute acid pretreatment of rice straw, subjecting it to $60^{\circ} \mathrm{C} \mathrm{CBP}$ fermentation with Clostridium sp. DBT-IOC-C19 and Thermoanaerobacter sp. DBT-IOC-X2, yielding an ethanol titer around $6.5 \mathrm{~g} / \mathrm{L}$. Liu et al. (2020) [154] reached 83.3\% of the theoretical yield 
in fermenting sugarcane bagasse at $60{ }^{\circ} \mathrm{C}$ using $\mathrm{C}$. thermocellum DSM 1237 as the only fermenting microorganism.

Other noteworthy thermophiles that have attracted interest in the field of ethanol fermentation belong to the genera Caldicellulosiruptor and Geobacillus, although few recent reports of their performance in the fermentation of industrially relevant feedstocks to ethanol are available. Caldicellulosiruptor is an extreme thermophilic $\left(\mathrm{T}_{\mathrm{opt}} 65-78^{\circ} \mathrm{C}\right)$, noncellulosomal, lignocellulose-degrading bacterium genus [155]. Its members are capable of co-metabolizing C5 and C6 sugars to hydrogen, acetate, lactate, and (in small amounts) ethanol [155]. Chung et al. (2015) [156] showed ethanol production from not pretreated switchgrass in a one-pot process at $75^{\circ} \mathrm{C}$ using a strain of Caldicellulosiruptor bescii engineered to produce higher ethanol titers than the wild type. Producing ethanol near its boiling point (i.e., $78.3^{\circ} \mathrm{C}$ ) is a strategy to alleviate its toxicity towards the fermenting microorganism, because the product is readily removed from the reaction vessel while fermentation is running. The works of Straub et al. [157-159] focused on the hydrolyzing activity of an engineered $C$. bescii (whose fermentation products are directed towards ethanol) as a proxy to determine the extent of the recalcitrance of transgenic poplar with modified lignin content. Not pretreated milled (transgenic) biomass was hydrolyzed and converted to fermentation products with a maximum yield of around 90\% (compared to a $25 \%$ yield in the case of wild type poplar), corresponding to an ethanol concentration of $18.3 \mathrm{mM}$ [158]. Species of the genus Geobacillus, although not well studied yet, are known to ferment both $\mathrm{C} 6$ and $\mathrm{C} 5$ sugars deriving from lignocellulosic feedstocks at temperatures ranging from 40 to $70{ }^{\circ} \mathrm{C}$ because they are efficient cellulase and xylanase producers [144]. Their thermostable cellulolytic enzymes are of significant interest and often the focus of synthetic biology studies [48,51,160,161]. Records of Geobacillus strains fermenting model substrates or lignocellulosic biomasses position microorganisms belonging to this genus as candidates for CBP applications, although their competitiveness is still to be established [48,155]. In recent work, Bibra et al. (2020) [162] presented the use of $G$. thermoglucosidasius and Thermoanaerobacter ethanolicus to produce ethanol from food waste in a single pot process at $60^{\circ} \mathrm{C}$, achieving an ethanol yield of $16.1 \mathrm{~g} / \mathrm{L}$.

Despite the advantages offered by the previously described wild-type organisms, the use of genetic manipulation is sometimes mandatory to ensure $2 \mathrm{G}$ ethanol production is economically feasible. In addition to the already cited examples, some other recent reports of genetic engineering thermophilic bacteria are summarized in Table 3. Increasing the ethanol titer is the main objective of such manipulations and this could be achieved either by (i) expanding the microorganisms' range of fermentable sugars $[138,142]$, (ii) deleting genes that encode for enzymes involved in the formation of by-products [163], or (iii) increasing the strain tolerance toward chemical inhibitors or ethanol itself. With this aim, Tian et al. (2017) [164] designed a C. thermocellum mutant overexpressing the glyceraldehyde 3-phosphate dehydrogenase of T. saccharolyticum. This mutant showed a faster growth rate in the presence of inhibiting concentration of ethanol (i.e., $25 \mathrm{~g} / \mathrm{L}$ ) compared to the wild-type strain. Moreover, the ethanol titer achieved by the mutant was increased by $28 \%$ compared to the control. By comparison, Kim et al. (2018) [165] aimed to achieve an increased tolerance toward hydroxymethyl-2-furfural (HMF) and acetate, which are two of the main growth and fermentation inhibitors that are produced during pretreatment. Because high intracellular levels of polyamine such as spermidine are reported to improve tolerance against furans in S. cerevisiae, Kim et al. (2015) [166] overexpressed in C. thermocellum its native spermidine synthase. The mutant's tolerance was significantly increased compared to the control. Similarly, its growth rate and ethanol productivity increased by 24 and $120 \%$, respectively. Given that in SSF and CBP architectures the fermenting microorganisms are exposed to high concentrations of toxic chemicals, it is reasonable to argue that, for a rapid industrial adoption of thermophilic microorganisms, more efforts should be made towards the genetic manipulation of the microbial strains used. Nevertheless, it is also important to consider that the large-scale implementation of genetically modified organisms (GMOs) may raise concerns from the perspective of public 
and environmental health, especially in countries in which GMO regulation is very strict (e.g., the EU). Conversely, if biocontainment is practiced, the use of GMOs is generally accepted in the USA. On this matter, Limayem et al. (2012) [167] described the application of the microbial risk assessment (MRA) approach, currently employed by the World Trade Organization (WTO) to estimate and characterize the risks related to food products, as a tool to detect and suppress microbial dissemination at an early stage in the biorefining of LCBs to ethanol. 
Table 2. Examples of thermophiles implementation into bioethanol fermentation using industrially relevant feedstocks.

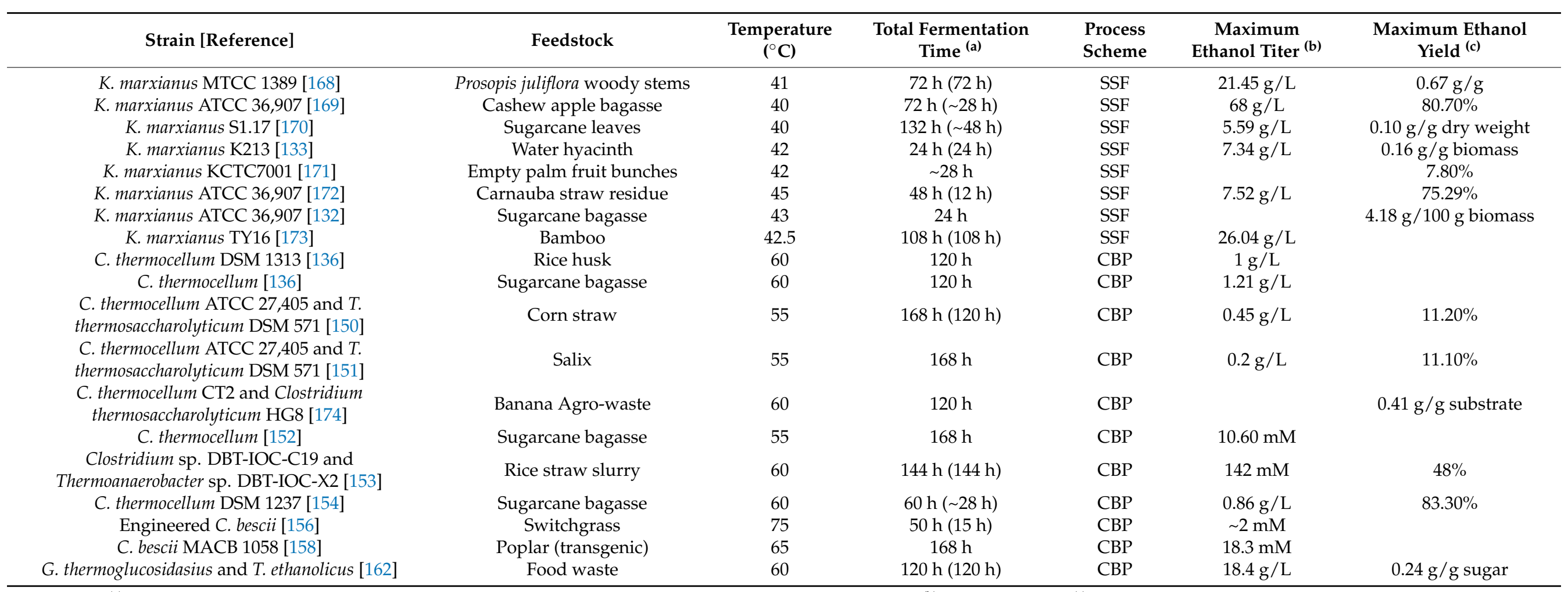

${ }^{(a)}$ If available in the source paper, the time at which the ethanol titer reached its maximum is reported in brackets. ${ }^{(b)}$ Ethanol titers and ${ }^{(c)}$ yields are reported as specified in the source paper. 
Table 3. Examples of genetically engineered thermophiles to increasing the ethanol titer.

\section{Strain [Reference]}

C. thermocellum DSM1313 [142]

C. thermocellum DSM1313 [143]

C. thermocellum DSM1313 $\Delta$ hpt $\Delta$ hydG [163]

C. thermocellum [164]
C. thermocellum [165]

C. thermocellum [175]

T. thermosaccharolyticum [138]

T. saccharolyticum, T. thermosaccharolyticum, $T$. xylanolyticum, T. mathranii, and C.

$$
\text { thermocellum [176] }
$$

Thermoanaerobacterium aotearoense

SCUT27/Dldh [177]

C. bescii $\Delta l d h[156]$

Protein Function (Gene)

Xylose isomerase $(x y l A)$, xylulokinase $(x y l B)$

Bifunctional alcohol dehydrogenases $(a d h E)$,

$\mathrm{NADH}$-dependent reduced ferredoxin:NADP+

oxidoreductase complex $(n f n A / B)$, and NADPH-

dependent alcohol dehydrogenase $(a d h A)$

Lactate dehydrogenase $(l d h)$, pyruvate-formate lyase

$(p f l)$, and phosphotransacetylase and acetate

$$
\text { kinase (pta-ack) }
$$

Gglyceraldehyde 3-phosphate dehydrogenase (gapdh)

$$
\text { Spermidine synthase (speE) }
$$

Ion-translocating reduced ferredoxin: NAD+

oxidoreductase $(r n f)$ and hydrogenase maturation

$$
\text { gene (hydG) }
$$

A-D-xylosidase $(\alpha$-Xylp_1211), $\alpha$-L-galactosidases

$(\alpha$-L-Galp_687 and 697), $\beta$-D-xylosidase $(\beta$-Xylp_1710)

and $\alpha$-L-arabinofuranosidases ( $\alpha$-Araf 996 and 1120)

$$
\text { Hydrogenase }\left(h f_{s} B\right)
$$

Pyruvate formate lyase-activating protein A ( $p f l A)$

Bi-functional acetyl-CoA thioesterase/ alcohol dehydrogenase (adhB) and bi-functional acetaldehyde/alcohol dehydrogenase (adhE)

Source Organism

T. ethanolicus

T. saccharolyticum

Self, knockout

T. saccharolyticum

Self, overexpression

Self, overexpression, and knockout,

respectively

Herbinix spp.

Self, knockout

Self, knockout

Thermoanaerobacter pseudethanolicus $39 E$

\section{Effect}

Enabled xylose co-fermentation.

Enhanced ethanol production.

Enhanced ethanol production

Enhanced ethanol tolerance.

Enhanced acetate and HMF tolerance.

Enhanced ethanol production

Conferred ability to deconstruct GAX component of corn fiber

Enhanced ethanol production.

Enhanced ethanol tolerance and production

Enabled ethanol fermentation at high temperatures. 


\section{Conclusions}

One of the possible countermeasures to decrease the atmospheric levels of carbon dioxide (one of the major GHGs responsible for global warming) is to replace fossil fuels with carbon-neutral alternatives, such as bioethanol. However, at present, the most easily produced and, therefore, mainly commercialized, kind of biofuel is first-generation (1G) bioethanol (crop-derived). Unfortunately, its global use is not sustainable given its competition with food and feed productions. A possible solution to the food vs. fuel debate is the use of non-edible lignocellulosic biomasses (LCBs) as a feedstock to produce second-generation $(2 \mathrm{G}$ ) bioethanol. Although LCBs are abundant, widespread, and cheap, they are significantly more resistant to the physical, chemical, and enzymatic treatments used to break down them into simple sugars that can be fermented to bioethanol.

This review highlights the progress and the potential in deploying thermophilic and thermostable enzymes and microorganisms in current $2 \mathrm{G}$ bioethanol production, for which widespread use has been hampered by the lack of both appropriate heterologous expression systems [121] and genetic manipulation tools. As discussed above, a profound redesign of the whole production process to implement the use of thermophiles is unlikely to be successful at present, because companies acting in this field would be required to implement additional investments to adapt existing production plants to run at higher temperatures. In contrast, companies producing $2 \mathrm{G}$ bioethanol are more likely to implement thermophilic enzymes and microorganisms in specific phases of the current process, which we identified as "windows of opportunity". These opportunities are stages of the process in which the temperature is already high within the current setup, such as (i) the cooling phase after pretreatments and (ii) the saccharification step itself. The use of thermophilic microorganisms during the fermentation phase would also allow the setup of a one-pot/one-phase (thermophilic) SSF, which would lead to (i) the need for fewer bioreactors, (ii) a decreased process time, (iii) a minimized risk of contamination, (iv) the direct fermentation of sugars into ethanol and, in turn, (v) a decreased product-inhibition effect of sugars on hydrolytic enzymes. Moreover, a thermophilic SSF would enable the integration of a continuous product separation process (i.e., ethanol distillation). However, the production of $2 \mathrm{G}$ ethanol by exclusively employing thermophilic microbial cell factories still requires significant scientific research aimed at genetic manipulation. Moreover, it is our opinion that more research should be undertaken to study the catalytic activity of thermophilic enzymes on industrially relevant LCBs, rather than only using synthetic polymers.

Author Contributions: Conceptualization, S.F.; Analysis of literature and writing-original draft preparation, L.Z., A.S., M.D.S. and S.F.; writing-review and editing, N.F. and S.F.; Supervision: S.F. All authors have read and agreed to the published version of the manuscript.

Funding: This research received no external funding.

Institutional Review Board Statement: Not applicable.

Informed Consent Statement: Not applicable.

Conflicts of Interest: The authors declare no conflict of interest.

\section{References}

1. Tans, P.; Keeling, R. Trends in Atmospheric Carbon Dioxide. Available online: https://gml.noaa.gov/ccgg/trends/ (accessed on 29 July 2021).

2. Collins, M.; Knutti, R.; Arblaster, J.; Dufresne, J.-L.; Fichefet, T.; Friedlingstein, P.; Gao, X.; Gutowski, W.J.; Johns, T.; Krinner, G.; et al. Long-term Climate Change: Projections, Commitments and Irreversibility. In Climate Change 2013-The Physical Science Basis; Stocker, T.F., Qin, D., Plattner, G.-K., Tignor, M.M.B., Allen, S.K., Boschung, J., Nauels, A., Xia, Y., Bex, V., Midgley, P.M., Eds.; Intergovernmental Panel on Climate Change; Cambridge University Press: Cambridge, UK, 2013; pp. 1029-1136. ISBN 9781107057991.

3. Intergovernmental Panel on Climate Change. Climate Change 2014 Mitigation of Climate Change; Cambridge University Press: Cambridge, UK, 2014; ISBN 9781107654815. [CrossRef] 
4. Kang, Q.; Appels, L.; Tan, T.; Dewil, R. Bioethanol from lignocellulosic biomass: Current findings determine research priorities. Sci. World J. 2014, 2014, 298153. [CrossRef]

5. Sharma, B.; Larroche, C.; Dussap, C.G. Comprehensive assessment of 2G bioethanol production. Bioresour. Technol. 2020, 313, 123630. [CrossRef] [PubMed]

6. Sharma, D.; Saini, A. Lignocellulosic Ethanol Production from a Biorefinery Perspective; Springer: Singapore, 2020; ISBN 978-981-154572-6. [CrossRef]

7. Thompson, P.B. The agricultural ethics of biofuels: The food vs. fuel debate. Agriculture 2012, 2, 339-358. [CrossRef]

8. Prasad, S.; Ingle, A.P. Impacts of sustainable biofuels production from biomass. In Sustainable Bioenergy; Rai, M., Ingle, A.P., Eds.; Elsevier: Amsterdam, The Netherlands, 2019; Chapter 12, pp. 327-346. ISBN 978-0-12-817654-2. [CrossRef]

9. von Lampe, M. Economic Assessment of Biofuel Support Policies. 2008. Available online: https://trid.trb.org/view/864830 (accessed on 1 July 2021).

10. Stephens, E.; Ross, I.L.; Mussgnug, J.H.; Wagner, L.D.; Borowitzka, M.A.; Posten, C.; Kruse, O.; Hankamer, B. Future prospects of microalgal biofuel production systems. Trends Plant Sci. 2010, 15, 554-564. [CrossRef] [PubMed]

11. Mayfield, C.A.; Foster, C.D.; Smith, C.T.; Gan, J.; Fox, S. Opportunities, barriers, and strategies for forest bioenergy and bio-based product development in the Southern United States. Biomass Bioenergy 2007, 31, 631-637. [CrossRef]

12. Stephen, J.D.; Mabee, W.E.; Saddler, J.N. Will second-generation ethanol be able to compete with first-generation ethanol? Opportunities for cost reduction. Biofuels Bioprod. Biorefin. 2012, 6, 159-176. [CrossRef]

13. Lynd, L.R.; Wyman, C.E.; Gerngross, T.U. Biocommodity engineering. Biotechnol. Prog. 1999, 15, 777-793. [CrossRef]

14. Chen, H. Biotechnology of Lignocellulose: Theory and Practice; Chemical Industry Press and Springer: Beijing, China, 2014; ISBN 9789400768987. [CrossRef]

15. O'Sullivan, A.C. Cellulose: The structure slowly unravels. Cellulose 1997, 4, 173-207. [CrossRef]

16. Karnaouri, A.; Matsakas, L.; Topakas, E.; Rova, U.; Christakopoulos, P. Development of thermophilic tailor-made enzyme mixtures for the bioconversion of agricultural and forest residues. Front. Microbiol. 2016, 7, 177. [CrossRef]

17. Chen, Y.A.; Zhou, Y.; Liu, D.; Zhao, X.; Qin, Y. Evaluation of the action of Tween 20 non-ionic surfactant during enzymatic hydrolysis of lignocellulose: Pretreatment, hydrolysis conditions and lignin structure. Bioresour. Technol. 2018, 269, 329-338. [CrossRef]

18. Balat, M.; Balat, H.; Öz, C. Progress in bioethanol processing. Prog. Energy Combust. Sci. 2008, 34, 551-573. [CrossRef]

19. Lombard, V.; Golaconda Ramulu, H.; Drula, E.; Coutinho, P.M.; Henrissat, B. The carbohydrate-active enzymes database (CAZy) in 2013. Nucleic Acids Res. 2014, 42, 490-495. [CrossRef] [PubMed]

20. Saha, B.C. Hemicellulose bioconversion. J. Ind. Microbiol. Biotechnol. 2003, 30, 279-291. [CrossRef] [PubMed]

21. Aulitto, M.; Fusco, S.; Limauro, D.; Fiorentino, G.; Bartolucci, S.; Contursi, P. Galactomannan degradation by thermophilic enzymes: A hot topic for biotechnological applications. World J. Microbiol. Biotechnol. 2019, 35, 32. [CrossRef]

22. Himmel, M.E.; Ding, S.-Y.; Johnson, D.K.; Adney, W.S.; Nimlos, M.R.; Brady, J.W.; Foust, T.D. Biomass Recalcitrance: Engineering Plants and Enzymes for Biofuels Production. Science 2007, 315, 804-807. [CrossRef]

23. Demirbas, A. Use of algae as biofuel sources. Energy Convers. Manag. 2010, 51, 2738-2749. [CrossRef]

24. Shah, S.H.; Raja, I.A.; Rizwan, M.; Rashid, N.; Mahmood, Q.; Shah, F.A.; Pervez, A. Potential of microalgal biodiesel production and its sustainability perspectives in Pakistan. Renew. Sustain. Energy Rev. 2018, 81, 76-92. [CrossRef]

25. Bharathiraja, B.; Chakravarthy, M.; Ranjith Kumar, R.; Yogendran, D.; Yuvaraj, D.; Jayamuthunagai, J.; Praveen Kumar, R.; Palani, S. Aquatic biomass (algae) as a future feed stock for bio-refineries: A review on cultivation, processing and products. Renew. Sustain. Energy Rev. 2015, 47, 634-653. [CrossRef]

26. Katiyar, R.; Gurjar, B.R.; Biswas, S.; Pruthi, V.; Kumar, N.; Kumar, P. Microalgae: An emerging source of energy based bio-products and a solution for environmental issues. Renew. Sustain. Energy Rev. 2017, 72, 1083-1093. [CrossRef]

27. Zuliani, L.; Frison, N.; Jelic, A.; Fatone, F.; Bolzonella, D.; Ballottari, M. Microalgae cultivation on anaerobic digestate of municipalwastewater, sewage sludge and agro-waste. Int. J. Mol. Sci. 2016, 17, 1692. [CrossRef]

28. Passell, H.; Dhaliwal, H.; Reno, M.; Wu, B.; Ben Amotz, A.; Ivry, E.; Gay, M.; Czartoski, T.; Laurin, L.; Ayer, N. Algae biodiesel life cycle assessment using current commercial data. J. Environ. Manag. 2013, 129, 103-111. [CrossRef]

29. Mu, D.; Min, M.; Krohn, B.; Mullins, K.A.; Ruan, R.; Hill, J. Life cycle environmental impacts of wastewater-based algal biofuels. Environ. Sci. Technol. 2014, 48, 11696-11704. [CrossRef] [PubMed]

30. Pragya, N.; Pandey, K.K. Life cycle assessment of green diesel production from microalgae. Renew. Energy 2016, 86, 623-632. [CrossRef]

31. Adams, C.; Godfrey, V.; Wahlen, B.; Seefeldt, L.; Bugbee, B. Understanding precision nitrogen stress to optimize the growth and lipid content tradeoff in oleaginous green microalgae. Bioresour. Technol. 2013, 131, 188-194. [CrossRef] [PubMed]

32. Soratana, K.; Harper, W.F.; Landis, A.E. Microalgal biodiesel and the Renewable Fuel Standard's greenhouse gas requirement. Energy Policy 2012, 46, 498-510. [CrossRef]

33. Alalwan, H.A.; Alminshid, A.H.; Aljaafari, H.A.S. Promising evolution of biofuel generations. Subject review. Renew. Energy Focus 2019, 28, 127-139. [CrossRef]

34. de Farias Silva, C.E.; Bertucco, A. Bioethanol from microalgae and cyanobacteria: A review and technological outlook. Process Biochem. 2016, 51, 1833-1842. [CrossRef] 
35. Efroymson, R.A.; Dale, V.H.; Langholtz, M.H. Socioeconomic indicators for sustainable design and commercial development of algal biofuel systems. GCB Bioenergy 2017, 9, 1005-1023. [CrossRef]

36. Robak, K.; Balcerek, M. Current state-of-the-art in ethanol production from lignocellulosic feedstocks. Microbiol. Res. 2020, 240, 126534. [CrossRef]

37. Soltanian, S.; Aghbashlo, M.; Almasi, F.; Hosseinzadeh-Bandbafha, H.; Nizami, A.S.; Ok, Y.S.; Lam, S.S.; Tabatabaei, M. A critical review of the effects of pretreatment methods on the exergetic aspects of lignocellulosic biofuels. Energy Convers. Manag. 2020, 212, 112792. [CrossRef]

38. Hamelinck, C.N.; Van Hooijdonk, G.; Faaij, A.P.C. Ethanol from lignocellulosic biomass: Techno-economic performance in short-, middle- and long-term. Biomass Bioenergy 2005, 28, 384-410. [CrossRef]

39. Glasser, W.G.; Wright, R.S. Steam-assisted biomass fractionation. II. Fractionation behavior of various biomass resources. Biomass Bioenergy 1998, 14, 219-235. [CrossRef]

40. Sun, D.; Yang, Q.; Wang, Y.; Gao, H.; He, M.; Lin, X.; Lu, J.; Wang, Y.; Kang, H.; Alam, A.; et al. Distinct mechanisms of enzymatic saccharification and bioethanol conversion enhancement by three surfactants under steam explosion and mild chemical pretreatments in bioenergy Miscanthus. Ind. Crops Prod. 2020, 153, 112559. [CrossRef]

41. Aulitto, M.; Fusco, S.; Nickel, D.B.; Bartolucci, S.; Contursi, P.; Franzén, C.J. Seed culture pre-adaptation of Bacillus coagulans MA-13 improves lactic acid production in simultaneous saccharification and fermentation. Biotechnol. Biofuels 2019, 12, 45. [CrossRef]

42. Aulitto, M.; Fusco, S.; Bartolucci, S.; Franzén, C.J.; Contursi, P. Bacillus coagulans MA-13: A promising thermophilic and cellulolytic strain for the production of lactic acid from lignocellulosic hydrolysate. Biotechnol. Biofuels 2017, 10, 210. [CrossRef] [PubMed]

43. Chandel, A.K.; da Silva, S.S.; Singh, O.V. Detoxification of Lignocellulose Hydrolysates: Biochemical and Metabolic Engineering Toward White Biotechnology. Bioenergy Res. 2013, 6, 388-401. [CrossRef]

44. Valdivia, M.; Galan, J.L.; Laffarga, J.; Ramos, J.L. Biofuels 2020: Biorefineries based on lignocellulosic materials. Microb. Biotechnol. 2016, 9, 585-594. [CrossRef] [PubMed]

45. Zabed, H.; Sahu, J.N.; Boyce, A.N.; Faruq, G. Fuel ethanol production from lignocellulosic biomass: An overview on feedstocks and technological approaches. Renew. Sustain. Energy Rev. 2016, 66, 751-774. [CrossRef]

46. Toor, M.; Kumar, S.S.; Malyan, S.K.; Bishnoi, N.R.; Mathimani, T.; Rajendran, K.; Pugazhendhi, A. An overview on bioethanol production from lignocellulosic feedstocks. Chemosphere 2020, 242, 125080. [CrossRef] [PubMed]

47. Olofsson, K.; Bertilsson, M.; Lidén, G. A short review on SSF-An interesting process option for ethanol production from lignocellulosic feedstocks. Biotechnol. Biofuels 2008, 1, 7. [CrossRef]

48. Bhalla, A.; Bansal, N.; Kumar, S.; Bischoff, K.M.; Sani, R.K. Improved lignocellulose conversion to biofuels with thermophilic bacteria and thermostable enzymes. Bioresour. Technol. 2013, 128, 751-759. [CrossRef]

49. Shen, J.; Agblevor, F.A. Ethanol production of semi-simultaneous saccharification and fermentation from mixture of cotton gin waste and recycled paper sludge. Bioprocess Biosyst. Eng. 2011, 34, 33-43. [CrossRef]

50. Shen, J.; Agblevor, F.A. Modeling semi-simultaneous saccharification and fermentation of ethanol production from cellulose. Biomass Bioenergy 2010, 34, 1098-1107. [CrossRef]

51. Patel, A.; Shah, A.R. Integrated lignocellulosic biorefinery: Gateway for production of second generation ethanol and value added products. J. Bioresour. Bioprod. 2021, 6, 108-128. [CrossRef]

52. Olguin-Maciel, E.; Singh, A.; Chable-Villacis, R.; Tapia-Tussell, R.; Ruiz, H.A. Consolidated Bioprocessing, an Innovative Strategy towards Sustainability for Biofuels Production from Crop Residues: An Overview. Agronomy 2020, 10, 1834. [CrossRef]

53. Singh, S.; Shukla, L.; Khare, S.; Nain, L. Detection and Characterization of New Thermostable Endoglucanase from Aspergillus awamori Strain F 18. J. Mycol. Plant Pathol. 2011, 41, 97-103.

54. Rigoldi, F.; Donini, S.; Redaelli, A.; Parisini, E.; Gautieri, A. Review: Engineering of thermostable enzymes for industrial applications. APL Bioeng. 2018, 2, 011501. [CrossRef] [PubMed]

55. Böhme, B.; Moritz, B.; Wendler, J.; Hertel, T.C.; Ihling, C.; Brandt, W.; Pietzsch, M. Enzymatic activity and thermoresistance of improved microbial transglutaminase variants. Amino Acids 2020, 52, 313-326. [CrossRef]

56. Espliego, J.M.E.; Saiz, V.B.; Torregrosa-Crespo, J.; Luque, A.V.; Camacho Carrasco, M.L.; Pire, C.; Bonete, M.J.; Martínez-Espinosa, R.M. Extremophile Enzymes and Biotechnology. In Extremophiles; CRC Press: Boca Raton, FL, USA; Taylor \& Francis: Abingdon, UK, 2018; pp. 227-248. [CrossRef]

57. Margaryan, A.; Shahinyan, G.; Hovhannisyan, P.; Panosyan, H.; Birkeland, N.-K.; Trchounian, A. Geobacillus and Anoxybacillus spp. from Terrestrial Geothermal Springs Worldwide: Diversity and Biotechnological Applications. In Extremophiles in Eurasian Ecosystems: Ecology, Diversity, and Applications; Egamberdieva, D., Birkeland, N.-K., Panosyan, H., Li, W.-J., Eds.; Springer: Singapore, 2018; pp. 119-166. ISBN 978-981-13-0329-6. [CrossRef]

58. Viikari, L.; Alapuranen, M.; Puranen, T.; Vehmaanperä, J.; Siika-aho, M. Thermostable Enzymes in Lignocellulose Hydrolysis. In Biofuels; Olsson, L., Ed.; Springer: Berlin/Heidelberg, Germany, 2007; pp. 121-145. ISBN 978-3-540-73651-6. [CrossRef]

59. Taylor, M.P.; Eley, K.L.; Martin, S.; Tuffin, M.I.; Burton, S.G.; Cowan, D.A. Thermophilic ethanologenesis: Future prospects for second-generation bioethanol production. Trends Biotechnol. 2009, 27, 398-405. [CrossRef] [PubMed]

60. Arora, R.; Behera, S.; Kumar, S. Bioprospecting thermophilic/thermotolerant microbes for production of lignocellulosic ethanol: A future perspective. Renew. Sustain. Energy Rev. 2015, 51, 699-717. [CrossRef] 
61. Di Donato, P.; Finore, I.; Poli, A.; Nicolaus, B.; Lama, L. The production of second generation bioethanol: The biotechnology potential of thermophilic bacteria. J. Clean. Prod. 2019, 233, 1410-1417. [CrossRef]

62. Linares-Pasten, J.; Andersson, M.; Karlsson, E. Thermostable Glycoside Hydrolases in Biorefinery Technologies. Curr. Biotechnol. 2014, 3, 26-44. [CrossRef]

63. Kucharska, K.; Rybarczyk, P.; Hołowacz, I.; Łukajtis, R.; Glinka, M.; Kamiński, M. Pretreatment of lignocellulosic materials as substrates for fermentation processes. Molecules 2018, 23, 2937. [CrossRef] [PubMed]

64. Amin, F.R.; Khalid, H.; Zhang, H.; Rahman, S.; Zhang, R.; Liu, G.; Chen, C. Pretreatment methods of lignocellulosic biomass for anaerobic digestion. AMB Express 2017, 7, 72. [CrossRef]

65. Baruah, J.; Nath, B.K.; Sharma, R.; Kumar, S.; Deka, R.C.; Baruah, D.C.; Kalita, E. Recent trends in the pretreatment of lignocellulosic biomass for value-added products. Front. Energy Res. 2018, 6, 141. [CrossRef]

66. Rahmati, S.; Doherty, W.; Dubal, D.; Atanda, L.; Moghaddam, L.; Sonar, P.; Hessel, V.; Ostrikov, K. Pretreatment and fermentation of lignocellulosic biomass: Reaction mechanisms and process engineering. React. Chem. Eng. 2020, 5, 2017-2047. [CrossRef]

67. Agbor, V.B.; Cicek, N.; Sparling, R.; Berlin, A.; Levin, D.B. Biomass pretreatment: Fundamentals toward application. Biotechnol. Adv. 2011, 29, 675-685. [CrossRef]

68. Zhang, X.; Yu, H.; Huang, H.; Liu, Y. Evaluation of biological pretreatment with white rot fungi for the enzymatic hydrolysis of bamboo culms. Int. Biodeterior. Biodegrad. 2007, 60, 159-164. [CrossRef]

69. Martínez, Á.T.; Speranza, M.; Ruiz-Dueñas, F.J.; Ferreira, P.; Camarero, S.; Guillén, F.; Martínez, M.J.; Gutiérrez, A.; Del Río, J.C. Biodegradation of lignocellulosics: Microbial, chemical, and enzymatic aspects of the fungal attack of lignin. Int. Microbiol. 2005, 8, 195-204. [CrossRef] [PubMed]

70. Kumar, R.; Wyman, C.E. Effects of cellulase and xylanase enzymes on the deconstruction of solids from pretreatment of poplar by leading technologies. Biotechnol. Prog. 2009, 25, 302-314. [CrossRef] [PubMed]

71. Mandels, M.; Weber, J.; Parizek, R. Enhanced cellulase production by a mutant of Trichoderma viride. Appl. Microbiol. 1971, 21, 152-154. [CrossRef] [PubMed]

72. Fenel, F.; Zitting, A.J.; Kantelinen, A. Increased alkali stability in Trichoderma reesei endo-1,4- $\beta$-xylanase II by site directed mutagenesis. J. Biotechnol. 2006, 121, 102-107. [CrossRef] [PubMed]

73. Liu, C.-L.; Wang, X.-F.; Niu, J.-L.; Lü, Y.-C.; Guo, P.; Shen, H.-L.; Cui, Z.-J. Composition diversity of the multifunctional bacterium community NSC-7. Huan Jing Ke Xue = Huanjing Kexue 2009, 30, 2112-2117.

74. Wongwilaiwalin, S.; Rattanachomsri, U.; Laothanachareon, T.; Eurwilaichitr, L.; Igarashi, Y.; Champreda, V. Analysis of a thermophilic lignocellulose degrading microbial consortium and multi-species lignocellulolytic enzyme system. Enzym. Microb. Technol. 2010, 47, 283-290. [CrossRef]

75. Wang, W.; Yan, L.; Cui, Z.; Gao, Y.; Wang, Y.; Jing, R. Characterization of a microbial consortium capable of degrading lignocellulose. Bioresour. Technol. 2011, 102, 9321-9324. [CrossRef]

76. Feng, Y.; Yu, Y.; Wang, X.; Qu, Y.; Li, D.; He, W.; Kim, B.H. Degradation of raw corn stover powder (RCSP) by an enriched microbial consortium and its community structure. Bioresour. Technol. 2011, 102, 742-747. [CrossRef]

77. Haruta, S.; Cui, Z.; Huang, Z.; Li, M.; Ishii, M.; Igarashi, Y. Construction of a stable microbial community with high cellulosedegradation ability. Appl. Microbiol. Biotechnol. 2002, 59, 529-534. [CrossRef]

78. Strazzulli, A.; Fusco, S.; Cobucci-Ponzano, B.; Moracci, M.; Contursi, P. Metagenomics of microbial and viral life in terrestrial geothermal environments. Rev. Environ. Sci. Biotechnol. 2017, 16, 425-454. [CrossRef]

79. Graham, J.E.; Clark, M.E.; Nadler, D.C.; Huffer, S.; Chokhawala, H.A.; Rowland, S.E.; Blanch, H.W.; Clark, D.S.; Robb, F.T. Identification and characterization of a multidomain hyperthermophilic cellulase from an archaeal enrichment. Nat. Commun. 2011, 2, 375. [CrossRef]

80. Elleuche, S.; Schröder, C.; Sahm, K.; Antranikian, G. Extremozymes-biocatalysts with unique properties from extremophilic microorganisms. Curr. Opin. Biotechnol. 2014, 29, 116-123. [CrossRef] [PubMed]

81. Ebaid, R.; Wang, H.; Sha, C.; Abomohra, A.E.F.; Shao, W. Recent trends in hyperthermophilic enzymes production and future perspectives for biofuel industry: A critical review. J. Clean. Prod. 2019, 238, 117925. [CrossRef]

82. Cobucci-Ponzano, B.; Ionata, E.; La Cara, F.; Morana, A.; Ferrara, M.C.; Maurelli, L.; Strazzulli, A.; Giglio, R.; Moracci, M. Extremophilic (Hemi)cellulolytic Microorganisms and Enzymes. In Lignocellulose Conversion: Enzymatic and Microbial Tools for Bioethanol Production; Faraco, V., Ed.; Springer: Berlin/Heidelberg, Germany, 2013; pp. 111-130. ISBN 978-3-642-37861-4. [CrossRef]

83. Banerjee, G.; Car, S.; Scott-Craig, J.S.; Borrusch, M.S.; Walton, J.D. Rapid optimization of enzyme mixtures for deconstruction of diverse pretreatment/biomass feedstock combinations. Biotechnol. Biofuels 2010, 3, 22. [CrossRef] [PubMed]

84. Chylenski, P.; Forsberg, Z.; Ståhlberg, J.; Várnai, A.; Lersch, M.; Bengtsson, O.; Sæbø, S.; Horn, S.J.; Eijsink, V.G.H. Development of minimal enzyme cocktails for hydrolysis of sulfite-pulped lignocellulosic biomass. J. Biotechnol. 2017, 246, 16-23. [CrossRef] [PubMed]

85. Kallioinen, A.; Puranen, T.; Siika-Aho, M. Mixtures of thermostable enzymes show high performance in biomass saccharification. Appl. Biochem. Biotechnol. 2014, 173, 1038-1056. [CrossRef]

86. Hassan, O.; Ling, T.P.; Maskat, M.Y.; Illias, R.M.; Badri, K.; Jahim, J.; Mahadi, N.M. Optimization of pretreatments for the hydrolysis of oil palm empty fruit bunch fiber (EFBF) using enzyme mixtures. Biomass Bioenergy 2013, 56, 137-146. [CrossRef] 
87. Zhu, J.Y.; Pan, X.J.; Wang, G.S.; Gleisner, R. Sulfite pretreatment (SPORL) for robust enzymatic saccharification of spruce and red pine. Bioresour. Technol. 2009, 100, 2411-2418. [CrossRef]

88. Youngblood, A.; Zhu, J.; Scott, C.T. Ethanol Production from Woody Biomass: Silvicultural Opportunities for Suppressed Western Conifers. In Integrated Management of Carbon Sequestration and Biomass Utilization Opportunities in a Changing Climate; U.S. Department of Agriculture, Forest Service, Rocky Mountain Research Station: Fort Collins, CO, USA, 2010; pp. 169-184.

89. Wang, G.S.; Pan, X.J.; Zhu, J.Y.; Gleisner, R.; Rockwood, D. Sulfite pretreatment to overcome recalcitrance of lignocellulose (SPORL) for robust enzymatic saccharification of hardwoods. Biotechnol. Prog. 2009, 25, 1086-1093. [CrossRef]

90. Sassner, P.; Mårtensson, C.G.; Galbe, M.; Zacchi, G. Steam pretreatment of $\mathrm{H}_{2} \mathrm{SO}_{4}$-impregnated Salix for the production of bioethanol. Bioresour. Technol. 2008, 99, 137-145. [CrossRef]

91. Sternberg, D.; Vuayakumar, P.; Reese, E.T. $\beta$-Glucosidase: Microbial production and effect on enzymatic hydrolysis of cellulose. Can. J. Microbiol. 1977, 23, 139-147. [CrossRef]

92. Bernardi, A.V.; Yonamine, D.K.; Uyemura, S.A.; Dinamarco, T.M. A thermostable Aspergillus fumigatus gh7 endoglucanase over-expressed in pichia pastoris stimulates lignocellulosic biomass hydrolysis. Int. J. Mol. Sci. 2019, 20, 2261. [CrossRef]

93. Bagewadi, Z.K.; Mulla, S.I.; Ninnekar, H.Z. Purification and characterization of endo $\beta-1,4$-D-glucanase from Trichoderma harzianum strain HZN11 and its application in production of bioethanol from sweet sorghum bagasse. 3 Biotech 2016, 6, 101. [CrossRef] [PubMed]

94. Han, C.; Yang, R.; Sun, Y.; Liu, M.; Zhou, L.; Li, D. Identification and Characterization of a Novel Hyperthermostable Bifunctional Cellobiohydrolase- Xylanase Enzyme for Synergistic Effect With Commercial Cellulase on Pretreated Wheat Straw Degradation. Front. Bioeng. Biotechnol. 2020, 8, 296. [CrossRef]

95. Nascimento, C.V.; Souza, F.H.M.; Masui, D.C.; Leone, F.A.; Peralta, R.M.; Jorge, J.A.; Furriel, R.P.M. Purification and biochemical properties of a glucose-stimulated $\beta$-D-glucosidase produced by Humicola grisea var. thermoidea grown on sugarcane bagasse. $J$. Microbiol. 2010, 48, 53-62. [CrossRef] [PubMed]

96. Zhang, Z.; Wang, M.; Gao, R.; Yu, X.; Chen, G. Synergistic effect of thermostable $\beta$-glucosidase TN0602 and cellulase on cellulose hydrolysis. 3 Biotech 2017, 7, 54. [CrossRef] [PubMed]

97. Cintra, L.C.; da Costa, I.C.; de Oliveira, I.C.M.; Fernandes, A.G.; Faria, S.P.; Jesuíno, R.S.A.; Ravanal, M.C.; Eyzaguirre, J.; Ramos, L.P.; de Faria, F.P.; et al. The boosting effect of recombinant hemicellulases on the enzymatic hydrolysis of steam-treated sugarcane bagasse. Enzym. Microb. Technol. 2020, 133, 109447. [CrossRef]

98. Gonçalves, G.A.L.; Takasugi, Y.; Jia, L.; Mori, Y.; Noda, S.; Tanaka, T.; Ichinose, H.; Kamiya, N. Synergistic effect and application of xylanases as accessory enzymes to enhance the hydrolysis of pretreated bagasse. Enzym. Microb. Technol. 2015, 72, 16-24. [CrossRef]

99. Sepulchro, A.G.V.; Pellegrini, V.O.A.; Briganti, L.; de Araujo, E.A.; de Araujo, S.S.; Polikarpov, I. Transformation of xylan into value-added biocommodities using Thermobacillus composti GH10 xylanase. Carbohydr. Polym. 2020, 247, 116714. [CrossRef] [PubMed]

100. Katsimpouras, C.; Dimarogona, M.; Petropoulos, P.; Christakopoulos, P.; Topakas, E. A thermostable GH26 endo- $\beta$-mannanase from Myceliophthora thermophila capable of enhancing lignocellulose degradation. Appl. Microbiol. Biotechnol. 2016, 100, 8385-8397. [CrossRef]

101. Vaaje-Kolstad, G.; Westereng, B.; Horn, S.J.; Liu, Z.; Zhai, H.; Sørlie, M.; Eijsink, V.G.H. An Oxidative Enzyme Boosting the Enzymatic Conversion of Recalcitrant Polysaccharides. Science 2010, 330, 219-222. [CrossRef]

102. Cannella, D.; Möllers, K.B.; Frigaard, N.U.; Jensen, P.E.; Bjerrum, M.J.; Johansen, K.S.; Felby, C. Light-driven oxidation of polysaccharides by photosynthetic pigments and a metalloenzyme. Nat. Commun. 2016, 7, 11134. [CrossRef]

103. Villares, A.; Moreau, C.; Bennati-Granier, C.; Garajova, S.; Foucat, L.; Falourd, X.; Saake, B.; Berrin, J.G.; Cathala, B. Lytic polysaccharide monooxygenases disrupt the cellulose fibers structure. Sci. Rep. 2017, 7, 40262. [CrossRef] [PubMed]

104. Agrawal, D.; Basotra, N.; Balan, V.; Tsang, A.; Chadha, B.S. Discovery and Expression of Thermostable LPMOs from Thermophilic Fungi for Producing Efficient Lignocellulolytic Enzyme Cocktails. Appl. Biochem. Biotechnol. 2020, 191, 463-481. [CrossRef]

105. Peciulyte, A.; Samuelsson, L.; Olsson, L.; McFarland, K.C.; Frickmann, J.; Østergård, L.; Halvorsen, R.; Scott, B.R.; Johansen, K.S. Redox processes acidify and decarboxylate steam-pretreated lignocellulosic biomass and are modulated by LPMO and catalase. Biotechnol. Biofuels 2018, 11, 165. [CrossRef]

106. Scott, B.R.; Huang, H.Z.; Frickman, J.; Halvorsen, R.; Johansen, K.S. Catalase improves saccharification of lignocellulose by reducing lytic polysaccharide monooxygenase-associated enzyme inactivation. Biotechnol. Lett. 2016, 38, 425-434. [CrossRef]

107. Kim, S.J.; Joo, J.E.; Jeon, S.D.; Hyeon, J.E.; Kim, S.W.; Um, Y.S.; Han, S.O. Enhanced thermostability of mesophilic endoglucanase $\mathrm{Z}$ with a high catalytic activity at active temperatures. Int. J. Biol. Macromol. 2016, 86, 269-276. [CrossRef] [PubMed]

108. Ito, Y.; Ikeuchi, A.; Imamura, C. Advanced evolutionary molecular engineering to produce thermostable cellulase by using a small but efficient library. Protein Eng. Des. Sel. 2013, 26, 73-79. [CrossRef]

109. Wu, I.; Heel, T.; Arnold, F.H. Role of cysteine residues in thermal inactivation of fungal Cel6A cellobiohydrolases. Biochim. Biophys. Acta-Proteins Proteom. 2013, 1834, 1539-1544. [CrossRef] [PubMed]

110. Anbar, M.; Gul, O.; Lamed, R.; Sezerman, U.O.; Bayer, E.A. Improved thermostability of Clostridium thermocellum endoglucanase Cel8A by using consensus-guided mutagenesis. Appl. Environ. Microbiol. 2012, 78, 3458-3464. [CrossRef]

111. Wang, H.J.; Hsiao, Y.Y.; Chen, Y.P.; Ma, T.Y.; Tseng, C.P. Polarity alteration of a calcium site induces a hydrophobic interaction network and enhances Cel9A endoglucanase thermostability. Appl. Environ. Microbiol. 2016, 82, 1662-1674. [CrossRef] 
112. Wijma, H.J.; Floor, R.J.; Jekel, P.A.; Baker, D.; Marrink, S.J.; Janssen, D.B. Computationally designed libraries for rapid enzyme stabilization. Protein Eng. Des. Sel. 2014, 27, 49-58. [CrossRef]

113. Khersonsky, O.; Lipsh, R.; Avizemer, Z.; Ashani, Y.; Goldsmith, M.; Leader, H.; Dym, O.; Rogotner, S.; Trudeau, D.L.; Prilusky, J.; et al. Automated Design of Efficient and Functionally Diverse Enzyme Repertoires. Mol. Cell 2018, 72, 178-186.e5. [CrossRef]

114. Rathi, P.C.; Mulnaes, D.; Gohlke, H. VisualCNA: A GUI for interactive constraint network analysis and protein engineering for improving thermostability. Bioinformatics 2015, 31, 2394-2396. [CrossRef] [PubMed]

115. Liu, W.; Zhang, X.Z.; Zhang, Z.; Zhang, Y.H.P. Engineering of clostridium phytofermentans endoglucanase Cel5A for improved thermostability. Appl. Environ. Microbiol. 2010, 76, 4914-4917. [CrossRef] [PubMed]

116. Anbar, M.; Lamed, R.; Bayer, E.A. Thermostability Enhancement of Clostridium thermocellum Cellulosomal Endoglucanase Cel8A by a Single Glycine Substitution. ChemCatChem 2010, 2, 997-1003. [CrossRef]

117. Dana, C.M.; Saija, P.; Kal, S.M.; Bryan, M.B.; Blanch, H.W.; Clark, D.S. Biased clique shuffling reveals stabilizing mutations in cellulase Cel7A. Biotechnol. Bioeng. 2012, 109, 2710-2719. [CrossRef]

118. Chang, C.J.; Lee, C.C.; Chan, Y.T.; Trudeau, D.L.; Wu, M.H.; Tsai, C.H.; Yu, S.M.; Ho, T.H.D.; Wang, A.H.J.; Hsiao, C.D.; et al. Exploring the mechanism responsible for cellulase thermostability by structure-guided recombination. PLoS ONE 2016, 11, e0147485. [CrossRef] [PubMed]

119. Akcapinar, G.B.; Venturini, A.; Martelli, P.L.; Casadio, R.; Sezerman, U.O. Modulating the thermostability of Endoglucanase I from trichoderma reesei using computational approaches. Protein Eng. Des. Sel. 2015, 28, 127-135. [CrossRef]

120. Goedegebuur, F.; Dankmeyer, L.; Gualfetti, P.; Karkehabadi, S.; Hansson, H.; Jana, S.; Huynh, V.; Kelemen, B.R.; Kruithof, P.; Larenas, E.A.; et al. Improving the thermal stability of cellobiohydrolase Cel7A from Hypocrea jecorina by directed evolution. $J$. Biol. Chem. 2017, 292, 17418-17430. [CrossRef] [PubMed]

121. Aulitto, M.; Fusco, S.; Fiorentino, G.; Limauro, D.; Pedone, E.; Bartolucci, S.; Contursi, P. Thermus thermophilus as source of thermozymes for biotechnological applications: Homologous expression and biochemical characterization of an $\alpha$-galactosidase. Microb. Cell Fact. 2017, 16, 28. [CrossRef]

122. Aulitto, M.; Fusco, F.A.; Fiorentino, G.; Bartolucci, S.; Contursi, P.; Limauro, D. A thermophilic enzymatic cocktail for galactomannans degradation. Enzym. Microb. Technol. 2018, 111, 7-11. [CrossRef]

123. Kong, F.; Yang, J.; Zhen, Z.; Liang, T.; Zhu, D.; Gao, R.; Xie, G. Gene cloning and molecular characterization of a $\beta$-glucosidase from Thermotoga naphthophila RUK-10: An effective tool for synthesis of galacto-oligosaccharide and alkyl galactopyranosides. Chem. Res. Chinese Univ. 2015, 31, 774-780. [CrossRef]

124. Irwin, D.C.; Spezio, M.; Walker, L.P.; Wilson, D.B. Activity studies of eight purified cellulases: Specificity, synergism, and binding domain effects. Biotechnol. Bioeng. 1993, 42, 1002-1013. [CrossRef] [PubMed]

125. Fonseca, G.G.; Heinzle, E.; Wittmann, C.; Gombert, A.K. The yeast Kluyveromyces marxianus and its biotechnological potential. Appl. Microbiol. Biotechnol. 2008, 79, 339-354. [CrossRef] [PubMed]

126. Jansen, M.L.A.; Bracher, J.M.; Papapetridis, I.; Verhoeven, M.D.; de Bruijn, H.; de Waal, P.P.; van Maris, A.J.A.; Klaassen, P.; Pronk, J.T. Saccharomyces cerevisiae strains for second-generation ethanol production: From academic exploration to industrial implementation. FEMS Yeast Res. 2017, 17, fox044. [CrossRef] [PubMed]

127. Kuloyo, O.O.; du Preez, J.C.; del Prado García-Aparicio, M.; Kilian, S.G.; Steyn, L.; Görgens, J. Opuntia ficus-indica cladodes as feedstock for ethanol production by Kluyveromyces marxianus and Saccharomyces cerevisiae. World J. Microbiol. Biotechnol. 2014, 30, 3173-3183. [CrossRef]

128. Leonel, L.V.; Arruda, P.V.; Chandel, A.K.; Felipe, M.G.A.; Sene, L. Kluyveromyces marxianus: A potential biocatalyst of renewable chemicals and lignocellulosic ethanol production. Crit. Rev. Biotechnol. 2021, 1-22, 1-39. [CrossRef]

129. Nurcholis, M.; Lertwattanasakul, N.; Rodrussamee, N.; Kosaka, T.; Murata, M.; Yamada, M. Integration of comprehensive data and biotechnological tools for industrial applications of Kluyveromyces marxianus. Appl. Microbiol. Biotechnol. 2020, 104, 475-488. [CrossRef]

130. Karim, A.; Gerliani, N.; Aïder, M. Kluyveromyces marxianus: An emerging yeast cell factory for applications in food and biotechnology. Int. J. Food Microbiol. 2020, 333, 108818. [CrossRef] [PubMed]

131. Madeira, J.V., Jr.; Gombert, A.K. Towards high-temperature fuel ethanol production using Kluyveromyces marxianus: On the search for plug-in strains for the Brazilian sugarcane-based biorefinery. Biomass Bioenergy 2018, 119, 217-228. [CrossRef]

132. de Araujo Guilherme, A.; Dantas, P.V.F.; Padilha, C.E.A.; dos Santos, E.S.; de Macedo, G.R. Ethanol production from sugarcane bagasse: Use of different fermentation strategies to enhance an environmental-friendly process. J. Environ. Manag. 2019, 234, 44-51. [CrossRef]

133. Yan, J.; Wei, Z.; Wang, Q.; He, M.; Li, S.; Irbis, C. Bioethanol production from sodium hydroxide/hydrogen peroxide-pretreated water hyacinth via simultaneous saccharification and fermentation with a newly isolated thermotolerant Kluyveromyces marxianu strain. Bioresour. Technol. 2015, 193, 103-109. [CrossRef]

134. Demain, A.L.; Newcomb, M.; Wu, J.H.D. Cellulase, Clostridia, and Ethanol. Microbiol. Mol. Biol. Rev. 2005, 69, 124-154. [CrossRef] [PubMed]

135. Olson, D.G.; McBride, J.E.; Joe Shaw, A.; Lynd, L.R. Recent progress in consolidated bioprocessing. Curr. Opin. Biotechnol. 2012, 23, 396-405. [CrossRef]

136. Nisha, M.; Saranyah, K.; Shankar, M.; Saleena, L.M. Enhanced saccharification of lignocellulosic agricultural biomass and increased bioethanol titre using acclimated Clostridium thermocellum DSM1313. 3 Biotech 2017, 7, 35. [CrossRef] 
137. Lynd, L.R.; Guss, A.M.; Himmel, M.E.; Beri, D.; Herring, C.; Holwerda, E.K.; Murphy, S.J.; Olson, D.G.; Paye, J.; Rydzak, T.; et al. Advances in Consolidated Bioprocessing Using Clostridium thermocellum and Thermoanaerobacter saccharolyticum. In Industrial Biotechnology; Wiley-VCH Verlag GmbH \& Co. KGaA: Weinheim, Germany, 2016; pp. 365-394. [CrossRef]

138. Beri, D.; York, W.S.; Lynd, L.R.; Peña, M.J.; Herring, C.D. Development of a thermophilic coculture for corn fiber conversion to ethanol. Nat. Commun. 2020, 11, 1937. [CrossRef] [PubMed]

139. Du, Y.; Zou, W.; Zhang, K.; Ye, G.; Yang, J. Advances and Applications of Clostridium Co-culture Systems in Biotechnology. Front. Microbiol. 2020, 11, 1937. [CrossRef] [PubMed]

140. Liberato, V.; Benevenuti, C.; Coelho, F.; Botelho, A.; Amaral, P.; Pereira, N.; Ferreira, T. Clostridium sp. As bio-catalyst for fuels and chemicals production in a biorefinery context. Catalysts 2019, 9, 962. [CrossRef]

141. Froese, A.G.; Sparling, R. Cross-feeding and wheat straw extractives enhance growth of Clostridium thermocellum-containing co-cultures for consolidated bioprocessing. Bioprocess Biosyst. Eng. 2021, 44, 819-830. [CrossRef]

142. Xiong, W.; Reyes, L.H.; Michener, W.E.; Maness, P.C.; Chou, K.J. Engineering cellulolytic bacterium Clostridium thermocellum to co-ferment cellulose- and hemicellulose-derived sugars simultaneously. Biotechnol. Bioeng. 2018, 115, 1755-1763. [CrossRef]

143. Hon, S.; Olson, D.G.; Holwerda, E.K.; Lanahan, A.A.; Murphy, S.J.L.; Maloney, M.I.; Zheng, T.; Papanek, B.; Guss, A.M.; Lynd, L.R. The ethanol pathway from Thermoanaerobacterium saccharolyticum improves ethanol production in Clostridium thermocellum. Metab. Eng. 2017, 42, 175-184. [CrossRef]

144. Jiang, Y.; Xin, F.; Lu, J.; Dong, W.; Zhang, W.; Zhang, M.; Wu, H.; Ma, J.; Jiang, M. State of the art review of biofuels production from lignocellulose by thermophilic bacteria. Bioresour. Technol. 2017, 245, 1498-1506. [CrossRef] [PubMed]

145. Bing, R.G.; Sulis, D.B.; Wang, J.P.; Adams, M.W.W.; Kelly, R.M. Thermophilic microbial deconstruction and conversion of natural and transgenic lignocellulose. Environ. Microbiol. Rep. 2021, 13, 272-293. [CrossRef] [PubMed]

146. Scully, S.M.; Orlygsson, J. Recent advances in second generation ethanol production by thermophilic bacteria. Energies 2015, 8, 1-30. [CrossRef]

147. Herring, C.D.; Kenealy, W.R.; Joe Shaw, A.; Covalla, S.F.; Olson, D.G.; Zhang, J.; Ryan Sillers, W.; Tsakraklides, V.; Bardsley, J.S.; Rogers, S.R.; et al. Strain and bioprocess improvement of a thermophilic anaerobe for the production of ethanol from wood. Biotechnol. Biofuels 2016, 9, 125. [CrossRef]

148. Currie, D.H.; Herring, C.D.; Guss, A.M.; Olson, D.G.; Hogsett, D.A.; Lynd, L.R. Functional heterologous expression of an engineered full length CipA from Clostridium thermocellum in Thermoanaerobacterium saccharolyticum. Biotechnol. Biofuels $2013,6,32$. [CrossRef] [PubMed]

149. He, Q.; Hemme, C.L.; Jiang, H.; He, Z.; Zhou, J. Mechanisms of enhanced cellulosic bioethanol fermentation by co-cultivation of Clostridium and Thermoanaerobacter spp. Bioresour. Technol. 2011, 102, 9586-9592. [CrossRef]

150. Pang, J.; Hao, M.; Li, Y.; Liu, J.; Lan, H.; Zhang, Y.; Zhang, Q.; Liu, Z. Consolidated Bioprocessing Using Clostridium thermocellum and Thermoanaerobacterium thermosaccharolyticum Co-culture for Enhancing Ethanol Production from Corn Straw. BioResources 2018, 13, 8209-8221. [CrossRef]

151. Pang, J.; Hao, M.; Shi, Y.; Li, Y.; Zhu, M.; Hu, J.; Liu, J.; Zhang, Q.; Liu, Z. Enhancing the ethanol yield from salix using a Clostridium thermocellum and Thermoanaerobacterium thermosaccharolyticum co-culture system. BioResources 2019, 13, 5377-5393. [CrossRef]

152. Bu, J.; Tian, Q.Q.; Zhu, M.J. Enhanced Biodegradation of Sugar Cane Bagasse by Coculture of Clostridium thermocellum and Thermoanaerobacterium aotearoense Supplemented with CaCO3. Energy Fuels 2017, 31, 9477-9483. [CrossRef]

153. Singh, N.; Gupta, R.P.; Puri, S.K.; Mathur, A.S. Bioethanol production from pretreated whole slurry rice straw by thermophilic co-culture. Fuel 2021, 301, 121074. [CrossRef]

154. Liu, Y.; Xie, X.; Liu, W.; Xu, H.; Cao, Y. Consolidated bioprocess for bioethanol production from lignocellulosic biomass using Clostridium thermocellum DSM 1237. BioResources 2020, 15, 8355-8368. [CrossRef]

155. Blumer-Schuette, S.E.; Brown, S.D.; Sander, K.B.; Bayer, E.A.; Kataeva, I.; Zurawski, J.V.; Conway, J.M.; Adams, M.W.W.; Kelly, R.M. Thermophilic lignocellulose deconstruction. FEMS Microbiol. Rev. 2014, 38, 393-448. [CrossRef] [PubMed]

156. Chung, D.; Cha, M.; Snyder, E.N.; Elkins, J.G.; Guss, A.M.; Westpheling, J. Cellulosic ethanol production via consolidated bioprocessing at $75{ }^{\circ} \mathrm{C}$ by engineered Caldicellulosiruptor bescii. Biotechnol. Biofuels 2015, 8, 163. [CrossRef]

157. Straub, C.T.; Bing, R.G.; Wang, J.P.; Chiang, V.L.; Adams, M.W.W.; Kelly, R.M. Use of the lignocellulose-degrading bacterium Caldicellulosiruptor bescii to assess recalcitrance and conversion of wild-type and transgenic poplar. Biotechnol. Biofuels 2020, 13, 43. [CrossRef] [PubMed]

158. Straub, C.T.; Khatibi, P.A.; Wang, J.P.; Conway, J.M.; Williams-Rhaesa, A.M.; Peszlen, I.M.; Chiang, V.L.; Adams, M.W.W.; Kelly, R.M. Quantitative fermentation of unpretreated transgenic poplar by Caldicellulosiruptor bescii. Nat. Commun. 2019, 10, 3548. [CrossRef] [PubMed]

159. Straub, C.T.; Khatibi, P.A.; Otten, J.K.; Adams, M.W.W.; Kelly, R.M. Lignocellulose solubilization and conversion by extremely thermophilic Caldicellulosiruptor bescii improves by maintaining metabolic activity. Biotechnol. Bioeng. 2019, 116, 1901-1908. [CrossRef]

160. Zhu, D.; Adebisi, W.A.; Ahmad, F.; Sethupathy, S.; Danso, B.; Sun, J. Recent Development of Extremophilic Bacteria and Their Application in Biorefinery. Front. Bioeng. Biotechnol. 2020, 8, 483. [CrossRef]

161. Bhalla, A.; Bischoff, K.M.; Sani, R.K. Highly thermostable xylanase production from a thermophilic Geobacillus sp. strain WSUCF1 utilizing lignocellulosic biomass. Front. Bioeng. Biotechnol. 2015, 3, 84. [CrossRef] 
162. Bibra, M.; Rathinam, N.K.; Johnson, G.R.; Sani, R.K. Single pot biovalorization of food waste to ethanol by Geobacillus and Thermoanaerobacter spp. Renew. Energy 2020, 155, 1032-1041. [CrossRef]

163. Papanek, B.; Biswas, R.; Rydzak, T.; Guss, A.M. Elimination of metabolic pathways to all traditional fermentation products increases ethanol yields in Clostridium thermocellum. Metab. Eng. 2015, 32, 49-54. [CrossRef] [PubMed]

164. Tian, L.; Perot, S.J.; Stevenson, D.; Jacobson, T.; Lanahan, A.A.; Amador-Noguez, D.; Olson, D.G.; Lynd, L.R. Metabolome analysis reveals a role for glyceraldehyde 3-phosphate dehydrogenase in the inhibition of $C$. thermocellum by ethanol. Biotechnol. Biofuels 2017, 10, 276. [CrossRef]

165. Kim, S.K.; Westpheling, J. Engineering a spermidine biosynthetic pathway in Clostridium thermocellum results in increased resistance to furans and increased ethanol production. Metab. Eng. 2018, 49, 267-274. [CrossRef] [PubMed]

166. Kim, S.K.; Jin, Y.S.; Choi, I.G.; Park, Y.C.; Seo, J.H. Enhanced tolerance of Saccharomyces cerevisiae to multiple lignocellulosederived inhibitors through modulation of spermidine contents. Metab. Eng. 2015, 29, 46-55. [CrossRef]

167. Limayem, A.; Ricke, S.C. Lignocellulosic biomass for bioethanol production: Current perspectives, potential issues and future prospects. Prog. Energy Combust. Sci. 2012, 38, 449-467. [CrossRef]

168. Sivarathnakumar, S.; Jayamuthunagai, J.; Baskar, G.; Praveenkumar, R.; Selvakumari, I.A.E.; Bharathiraja, B. Bioethanol production from woody stem Prosopis juliflora using thermo tolerant yeast Kluyveromyces marxianus and its kinetics studies. Bioresour. Technol. 2019, 293, 122060. [CrossRef] [PubMed]

169. de Barros, E.M.; Carvalho, V.M.; Rodrigues, T.H.S.; Rocha, M.V.P.; Gonçalves, L.R.B. Comparison of strategies for the simultaneous saccharification and fermentation of cashew apple bagasse using a thermotolerant Kluyveromyces marxianus to enhance cellulosic ethanol production. Chem. Eng. J. 2017, 307, 939-947. [CrossRef]

170. Jutakanoke, R.; Tolieng, V.; Tanasupawat, S.; Akaracharanya, A. Ethanol Production from Sugarcane Leaves by Kluyveromyces marxianus S1.17, a Genome-Shuffling Mediated Transformant. BioResources 2017, 12, 1636-1646. [CrossRef]

171. Jung, Y.R.; Park, J.M.; Heo, S.Y.; Hong, W.K.; Lee, S.M.; Oh, B.R.; Park, S.M.; Seo, J.W.; Kim, C.H. Cellulolytic enzymes produced by a newly isolated soil fungus Penicillium sp. TG2 with potential for use in cellulosic ethanol production. Renew. Energy 2015, 76, 66-71. [CrossRef]

172. da Silva, F.L.; de Oliveira Campos, A.; dos Santos, D.A.; Batista Magalhães, E.R.; de Macedo, G.R.; dos Santos, E.S. Valorization of an agroextractive residue-Carnauba straw-for the production of bioethanol by simultaneous saccharification and fermentation (SSF). Renew. Energy 2018, 127, 661-669. [CrossRef]

173. Ganesan, S. Production of Bioethanol from Bamboo using Thermotolerant Yeast with Simultaneous Saccharification and Fermentation Process. Int. J. Curr. Microbiol. Appl. Sci. 2019, 8, 1718-1727. [CrossRef]

174. Harish Kumar Reddy, Y.; Srijana, M.; Madhusudhan Reddy, D.; Gopal, R. Coculture fermentation of banana agro-waste to ethanol by cellulolytic thermophilic Clostridium thermocellum CT2. Afr. J. Biotechnol. 2010, 9, 1926-1934. [CrossRef]

175. Lo, J.; Olson, D.G.; Murphy, S.J.L.; Tian, L.; Hon, S.; Lanahan, A.; Guss, A.M.; Lynd, L.R. Engineering electron metabolism to increase ethanol production in Clostridium thermocellum. Metab. Eng. 2017, 39, 71-79. [CrossRef] [PubMed]

176. Eminoğlu, A.; Murphy, S.J.L.; Maloney, M.; Lanahan, A.; Giannone, R.J.; Hettich, R.L.; Tripathi, S.A.; Beldüz, A.O.; Lynd, L.R.; Olson, D.G. Deletion of the hfsB gene increases ethanol production in Thermoanaerobacterium saccharolyticum and several other thermophilic anaerobic bacteria. Biotechnol. Biofuels 2017, 10, 282. [CrossRef] [PubMed]

177. Fu, H.; Luo, S.; Dai, K.; Qu, C.; Wang, J. Engineering Thermoanaerobacterium aotearoense SCUT27/ $\Delta$ ldh with pyruvate formate lyase-activating protein (PflA) knockout for enhanced ethanol tolerance and production. Process Biochem. 2021, 106, 184-190. [CrossRef] 